\title{
INCORPORATING THE THIRD PARTY BENEFICIARY PRINCIPLE IN NATURAL RESOURCE CONTRACTS
}

\author{
James Thuo Gathii*
}

\author{
TABLE OF CONTENTS
}

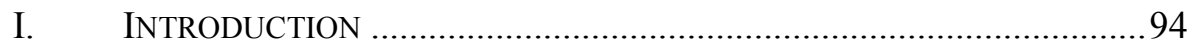

II. CURRENT EFFORTS AT ADDRESSING EXTRACTIVE RESOURCES .... 100

III. THE THIRD PARTY BENEFICIARY PRINCIPLE .................................. 102

A. Introduction to Third Party Beneficiary Principle .................... 102

B. The Evolution of Recognizing Third Party Beneficiary



C. The First Restatement of the Law of Contracts ........................107

D. The Second Restatement of the Law of Contracts.................... 109

E. Modern Application of Third Party Beneficiary Principle in the United States ................................................................. 110

F. Evolution of the Third Party Beneficiary Principle Abroad .... 112

IV. BASIS OF THIRD PARTY LEGAL INTERESTS IN RESOURCE

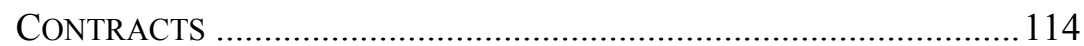

A. Consistency Between Wishes of Contracting Parties and Third Party Beneficiaries ........................................................ 114

B. Resource Development Should Benefit Local Citizens............. 117

C. Interests of Justice and Morality ............................................. 125

D. Public Policy Rationales ....................................................... 129

V. OBJECTIONS AND RESPONSES TO THIRD PARTY BENEFICIARY STANDING IN RESOURCE CONTRACTS ........................................... 133

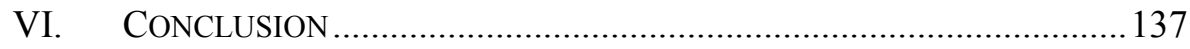

\footnotetext{
* Wing-Tat Lee Chair of International Law, Loyola University Chicago School of Law and Member of the African Commission on Human and Peoples' Rights Working Group on Extractive Industries, Human Rights and the Environment. I would like to thank Michael Weiss, Chad Nold, Nick Fedde, Chloe Bremer, Pierre Guigue and Griffen Thorne for their excellent research assistance.
} 


\section{INTRODUCTION}

Citizens of low-income, resource rich countries have absolutely no voice in the negotiation or signing of natural resource contracts between their governments and private investors, even though they are almost always deeply (and often detrimentally) affected by the terms of the contracts and resource extraction. To make matters worse, government officials in lowincome, resource rich countries often lack both capacity and experience to negotiate complex contracts with multinational corporations, which can ultimately harm both the government and its citizens. ${ }^{1}$ There is no symmetry between the negotiating ability of low-income, resource rich countries and experienced and vastly wealthy multinational corporations. It is notable that the issues involved go beyond bargaining power, resources and capacity; there is generally no transparency in either contract negotiations or in revenues that companies pay to access natural resources. However, this Article addresses a different aspect of natural resource contracting: the Third Party Beneficiary Principle and how it can protect the rights of citizens in third world countries.

When resource extraction harms local communities, those communities are often without legal remedy. ${ }^{2}$ Because these citizens did not sign the contract,

1 One commentator suggests:

There is an unavoidable conflict of interest between (usually foreign) naturalresource companies and host countries: The former want to minimize what they pay, while the latter need to maximize it. Well-designed, competitive, transparent auctions can generate much more revenue than sweetheart deals. Contracts, too, should be transparent, and should ensure that if prices soaras they have repeatedly - the windfall gain does not go only to the company.

Joseph E. Stiglitz, From Resource Curse to Blessing, Proj. SyndiCATE (Aug. 6, 2012), http:// www.project-syndicate.org/commentary/from-resource-curse-to-blessing-by-joseph-e--stiglitz. But see Terutomo Ozawa, A Newer Type of Foreign Investment in Third World Resource Development, in BrUCE MCKERN, TRANSNATIONAL CORPORATIONS AND THE EXPLOITATION OF NATURAL Resources 111-12 (10th ed. 1993) (claiming that "resource-rich but industrially undeveloped countries are learning quickly how to bargain for a greater share of benefits from the operation of foreign investors in extracting natural resources in their countries").

${ }^{2}$ For example, oil extraction in the Niger Delta has contaminated drinking water on which many local citizens depend, forcing those citizens to eat fish contaminated with oil and drink polluted water. To make matters worse, the Nigerian government allegedly denied citizens access to information about how oil extraction would harm them. Oil industry has brought poverty and pollution to Niger Delta, AMNESTY INT'L (June 30, 2009), http://www.amnesty.org/en/news-and-updates/news/oil-industry-has-brought-poverty-andpollution-to-niger-delta-20090630. Often, governments do the most damage. Human rights advocates have coined the term "natural resource curse," meaning that income from natural resources in resource-rich countries is often misappropriated by corrupt leaders-for example, Saddam Hussein used income from Iraq's natural oil to repress Iraqi citizens. 
they lack privity, and as non-parties to the contract, they consequently lack contractual remedies. For these reasons, classic contract law-in the absence of a promise to third parties and consideration from third parties - prohibits third parties from having standing to sue on that contract or to enforce the contract. $^{3}$ Therefore, it is crucial that third party communities in low-income, resource rich countries are granted third party beneficiary rights, which would give them the necessary standing to sue on the contract. ${ }^{4}$

Many recent examples demonstrate the necessity for third party beneficiary status. One prominent example arose when the Cree Nation of Quebec objected to a uranium mining project on its territory. ${ }^{5}$ The investor, Strateco Resources, sued Quebec, seeking a final decision to permit the project to proceed. ${ }^{6}$ When the Cree Nation filed an intervention action seeking to be joined in the suit with full rights of participation, Strateco Resources objected on the basis that the Cree were not privy to the negotiations for the approval of the mining project and therefore could not intervene in the action. ${ }^{7}$ Cree Nation Grand Chief Dr. Matthew Coon Come replied, arguing:

[T] he requirement of social acceptability as a condition for development in Eeyou Istchee is an essential aspect of the successful nation-to-nation relationship between the Crees and Quebec. Strateco's legal action represents a fundamental

Thomas I. Palley, Lifting the Natural Resource Curse, ForeIGn SERV. J. 55 (Dec. 2003), available at http://www.afsa.org/FSJ/1203/ index.html\#/57/zoomed. For a more in-depth discussion of harms toward citizens, see infra Part III.

${ }^{3}$ I will follow up this breakdown of the will theory of contracts by mapping contracting and its implications in twenty-first century natural resource contracts in a jointly authored piece: James Gathii \& Ibironke Odomosu-Ayanu, The Turn to Contractual Regimes and Contractual Responsibility in the Extractive Industry, 1 Bus. \& HuM. RTS. J. (forthcoming 2015).

4 In advocating for third party beneficiary rights, I do not suggest reducing any of the rights of investors. To illustrate, I do not advocate that all natural resource contracts between investors and governments of low-income, resource rich countries contain Calvo clauseswhich require investors to submit to the remedies available in the country with which they contract, thus forfeiting international remedies. JAMES THUO GATHI, WAR, COMMERCE, AND InTERnAtional LAW 157 (Oxford Univ. Press 2010). Rather, I argue that the Third Party Beneficiary Principle should exist to protect non-parties to contracts who could otherwise not protect themselves. This Principle does not reduce any investor rights, but instead affords an extra layer of protection to third world citizens.

${ }^{5}$ Henry Lazenby, Quebec First Nations Move to Intervene in Strateco Legal Proceedings, MINING WKLY. (Feb. 6, 2013), http://www.miningweekly.com/article/quebec-first-nations-mo ve-to-intervene-in-strateco-legal-proceedings-2013-02-06.

${ }^{6} I d$.

7 Jesse B. Staniforth, Strateco Tries to Sideline Cree Opposition, NATION (Feb. 8, 2013, 8:41 PM), http://www.nationnews.ca/strateco-tries-to-sideline-cree-opposition/. 
challenge to the principle of social acceptability, and to our treaty rights. We are committed to protecting our environment and our treaty rights, for current and future generations. ${ }^{8}$

Notably, unlike in the United States, France, and the United Kingdom, Canadian contract law does not recognize the Third Party Beneficiary Principle. $^{9}$

Another prominent example is the case between residents of Kitui County in Kenya and Fenxi Mining of China. ${ }^{10}$ The Mui community raised various concerns about the impact of the mining project on them and their environment. ${ }^{11}$ The citizens claimed that the contract was unfair, in part because it was signed in a hurry and denied the locals the benefits proposed in local mining legislation. ${ }^{12}$ The locals' representatives made a raft of recommendations, which were eventually left out of the Benefits Sharing Agreement that was presumably signed for their benefit. ${ }^{13}$ Suits against the government and several petitions in the case were filed, as recently as February 2014. ${ }^{14}$ To the extent that the representatives could not sue on the contract between the government of Kenya and Fenzi Mining of Kenya, this case demonstrates citizens' need for third party beneficiary rights. ${ }^{15}$

\footnotetext{
${ }^{8}$ Crees Move to Intervene in Legal Proceedings Commenced by Strateco Resources, CREE NATION OF Mistissini (Dec. 20, 2013), http://www.mistissini.ca/en/30-new-crees-move-to-in tervene-in-legal-proceedings-commenced-by-strateco-resources.html.

${ }^{9}$ Patrick Macklem, an indigenous rights scholar in Canada, suggests that Canada has had the most success with third party indigenous claims because the treaty process has forced recognition of sovereignty for indigenous peoples in Canada. PATRICK MACKLEM, INDIGENOUS DifFERENCE AND THE CONSTITUTION OF CANADA (2001).

${ }^{10}$ Forgotten in the Scramble for Lamu: A Position Paper on the LAPPSE Project in the Case of the Aweer and the Fisherfolk, Kenya Human Rights Commission (June 18, 2014, 2:20 PM), http://www.khrc.or.ke/resources/publications/doc details/69-forgotten-in-the-scram ble-for-lamua-position-paper-in-the-case-of-the-aweer-and-the-fisherfolk.html.

${ }^{11}$ See Musembi Nzengu, Kenya: Mui Coal Mining Case to Be Heard on February 21, STAR (Feb. 5, 2014), http://allafrica.com/stories/201402050574.html.

${ }^{12}$ Musembi Nzengu, Kenya: Mui Coal Deal 'Unfair,' StaR (July 14, 2014), http://allafri ca.com/stories/201407142310.html.

${ }^{13} I d$.

${ }_{15}^{14}$ Nzengu, supra note 11.

15 Another example that exemplifies the importance of obtaining third party beneficiary status arose in Turkana this year. For the first time in Turkana's history, landowners have been offered to own part of the proposed Lokichar-Lamu oil pipeline in a move aimed at defusing tensions over compensation for the land taken up by the project. George Omondi, Uhuru Offers Turkana Land Owners Oil Pipeline Shares in Wayleaves Deal, Bus. DAILy (June 23, 2014), http://www. businessdailyafrica.com/Uhuru-offers-Turkana-land-owners-oil-pipeline-shares-in-deal/-/53955 2/2359210/-/o6qtrkz/-/index.html.
} 
This Article proposes recognizing and applying the Third Party Beneficiary Principle in contracts between low-income, resource rich countries and natural resource investors. A major impetus for this project is the increasing recognition of the need to build on the available set of remedial regimes for violations of human rights by business actors. This project therefore supplements initiatives put in motion by the U.N. Guiding Principles on Human Rights to consider human rights risks and to find ways of addressing them in contract negotiations. ${ }^{16}$

In both common and civil law countries, third parties have standing to sue on a contract under certain circumstances. In the United States, the Second Restatement of Contracts recognizes third party beneficiary standing as a general principle and specifies certain categories of individuals as having standing to sue as third party beneficiaries. ${ }^{17}$ In many jurisdictions, there is a complex maze of approaches aimed at overcoming the privity doctrine. Stated most simply, the Third Party Beneficiary Principle is recognized where a contract is made for the benefit of a third party and allows such third party a right to enforce the contract by filing suit. ${ }^{18}$

The Third Party Beneficiary Principle is not intended to circumvent the will of the parties to a contract, but rather to effectuate the parties' intentions, especially where their contract was intended to benefit a third party. ${ }^{19}$ In addition, the Third Party Beneficiary Principle exists as a matter of justice and morality. Thus, third parties such as subsequent tenants or purchasers are often allowed to sue an engineer or a contractor for the performance of defective works or the failure to exercise due care and skill in construction

\footnotetext{
${ }^{16}$ Special Rep. of the U.N. Secretary General, Principles for Responsible Contracts: Integrating the Management of Human Rights Risks into State-Investor Contract Negotiations: Guidance for Negotiators, U.N. Doc. A/HRC/17/31/Add.3 (May 25, 2011) (by John Ruggie), available at http://www.ohchr.org/Documents/Issues/Business/A.HRC.17.31. Add.3.pdf (Principle 9 contemplates that business should have grievance mechanisms in place for non-contractual parties affected by a project). This Article argues that one can go beyond Principle 9, which contemplates only non-judicial (operational level) relief mechanisms.

17 See Restatement (SeCOnd) OF Contracts § 302 (1981).

18 See Drive Yourself Car Hire (London) Co. v. Strutt, [1953] 1 Q.B. 250, 272 (explaining that it was settled law for at least two hundred years prior to 1861 that a third party could enforce a contract that it was not a party to if it was made expressly for his benefit).

19 This may be more difficult to prove in the context of a government contract than it would be in the context of a commercial contract. One scholar notes that the third party must show that the terms of the government contract must "directly provide for liability to the third party," and that it is "not enough for a third party to show that the purpose of the government contract was to benefit the public." Wendy Netter Epstein, Contract Theory and the Failures of Public-Private Contracting, 34 CARDOZO L. REV. 2211, 2256 (2013) (citing Restatement (SECOND) OF CONTRACTS $§ 313$ (1981)).
} 
contracts. ${ }^{20}$ The remedies available in a suit by a third party beneficiary are contractual performance or damages for non-performance, specific performance or injunctive relief - the same remedies available upon breach to parties to a contract. In other words, third party beneficiaries have a cause of action for breach.

The recognition of third party beneficiary rights would supplement existing approaches to resolving problems in extractive industry operations, including contract and revenue transparency, codes of conduct, and the U.N. Norms on Business and Human Rights. A major weakness of these approaches is that they are not legally enforceable, because voluntary and non-binding approaches do not give rise to enforceable legal claims. This in turn reduces their transformative potential for those that suffer the unfortunate consequences of resource extraction and therefore would benefit most from having this principle.

In my view, adding Third Party Beneficiary law to existing approaches to resolving extractive industries problems would be an important supplement to the available toolkit. The Third Party Beneficiary Principle has the potential to tilt the incentives for investors and governments to pay more attention to vulnerable communities and peoples in resource extraction scenarios because contracts - unlike voluntary and non-binding codes - create enforceable obligations at the front-end. In fact, as I have argued elsewhere, the absence of a binding legal regime for accountability in the violent extraction of mineral resources is facilitated by weak states lacking effective control over their territory and by the extremely lucrative trading of natural resources. ${ }^{21}$

My argument is premised on rejecting the compartmentalization of public and private law in addressing resource extraction problems. By that I mean that the current framework for addressing problems, or externalities as economists would call them, that arise from private law dealings - such as contract law - are thought to be primarily resolved through public rather than private law. Thus, we see that many of the responses to the resource extraction problem are conceived in the public law arena, such as the "Ruggie Framework," 22 or in non-binding corporate codes of conduct.

\footnotetext{
${ }^{20}$ Michael Sayers, The Law Commission, Privity of Contract: Contracts for the BENEFIT OF THIRD PARTIEs 16 (1996), available at http://lawcommission.Justice.gov.uk/docs/ lc242_privity_of_contract_for_the_benefit_of_third_parties.pdf (last visited July 25, 2014) [hereinafter LAW COMMISSION REPORT].

${ }^{21}$ GATHII, supra note 4, at 237-42.

${ }^{22}$ See generally U.N. Human Rights Office of the High Comm'r, Guiding Principles on Business and Human Rights: Implementing the United Nations "Protect, Respect and Remedy" Framework, HR/PUB/11/04 (2011), available at http://www.ohchr.org/Documents/ Publications/GuidingPrinciplesBusinessHR_EN.pdf [hereinafter Ruggie Framework].
} 
These are all important ways of addressing the resource extraction problem. However, private law approaches, like the Third Party Beneficiary Principle, would powerfully complement these current approaches. The Third Party Beneficiary Principle would be one of the background rules against which contracts for negotiation of extractive resources would be conducted. As a result, even if beneficiary communities were unable to pursue remedies in court, the recognition of the Third Party Beneficiary Principle would likely influence the negotiation of contracts by requiring the parties to take into account the rights and interests of local communities who reside in communities where resources are extracted. ${ }^{23}$

The importance of adding the Third Party Beneficiary Principle is that the resource extraction problem arises from the contractual relations between lowincome, resource-rich countries and multinational corporations. Given that these contracts lay down the foundation upon which natural resource extraction proceeds, ${ }^{24}$ it is important to examine contractual remedies to the resource extraction problem. The need for contractual remedies is further underlined by how in some low-income, resource-rich countries. Resources are exploited for the private benefit of a small class of powerful actors, including corrupt politicians and foreign investors. In my view, the Third Party Beneficiary Principle is a critical step towards strengthening accountability within the extremely weak framework of economic actors in resource extraction. ${ }^{25}$ To the extent public international law has been unable to offer binding and enforceable rules to hold economic actors like corporations accountable for their conduct in the resource extraction context, it is important

\footnotetext{
${ }^{23}$ Epstein, supra note 19, at 2257-58. Professor Epstein suggests that companies would bid more accurately and would perform better if these rules were adopted. Though Professor Epstein argues that this result cannot be achieved unless there is a mandatory duty to act in the public interest, I believe that granting third party beneficiary rights to these citizens would achieve the same results.

${ }^{24}$ There are of course examples of extraction of natural resources that are not conducted through contractual relationships in many war torn countries.

${ }^{25}$ M. Sornarajah, Linking State Responsibility for Certain Harms Caused by Corporate Nationals Abroad to Civil Recourse in the Legal Systems of Home States, in TORTURE AS Tort: Comparative Perspectives on the Development of Transnational Human Rights Litigation 502 (Craig Scott ed. 2001). Sornarajah further argues that:

[A] developing state should be able to assert its rights of protection of its nationals when an alien causes damage in its state and its nationals are not provided relief in the home state of the alien in which his assets are situated Id. at 497. and to which he has repatriated profits of his operations in the host state.
} 
to resort to private law remedies such as the Third Party Beneficiary Principle. $^{26}$

\section{CURRENT EFForts AT AdDRESSING EXTRACTIVE RESOURCES}

Currently, there are two major approaches aimed at addressing extraction resources. $^{27}$ One approach involves voluntary or non-binding codes of conduct. Another approach requires using a variety of home state and international regulations. The first approach uses voluntary or non-binding codes of conduct. One of the oldest examples was a draft Code of Conduct for Transnational Corporations under the U.N. Center on Transnational Corporations. ${ }^{28}$ There are numerous examples of such voluntary codes, including such multi-stake holder initiatives as the Kimberley Transparency Initiative, ${ }^{29}$ the 2002 Extractive Industries Transparency Initiative, ${ }^{30}$ the U.N. Global Compact, ${ }^{31}$ the 2003 U.N. Norms on the Responsibilities of Transnational Corporations, and Other Business Enterprises with Regard to Human Rights. ${ }^{32}$ There are also industry specific and company specific codes. $^{33}$ The overwhelming majority of these codes were developed without

\footnotetext{
${ }^{26}$ I do not foreclose the possibility of re-orienting private international law in the direction of human rights as Upendra Baxi strongly argues we should. See Upendra BaXI, Mass Torts, Multinational Enterprise Liability and Private International Law, 276 RECUEIL DES COURS 307 (1999).

${ }^{27}$ Here I simplify a rather broad area by emphasizing the distinction between legally binding and non-legally binding approaches. For a good overview of another typology, see Oliver De Schutter, The Accountability of Multinationals for Human Rights Violations in European Law (Ctr. for Human Rights and Global Justice, Working Paper No. 1, 2004).

28 See Draft United Nations Code of Conduct on Transnational Corporations, 23 I.L.M 626 (1984).

29 See About: Kimberly Process, KimBerly Process, http://www.kimberleyprocess.com/ en/about (last visited Oct. 7, 2014).

${ }^{30}$ See History of EITI, EXTRACTIVE Indus. TransParenCy InITIATIVE, http://eiti.org/eiti/ history (last visited July 31, 2014).

31 Overview of the UN Global Compact, U.N. Global CомPACт, http://www.unglobal compact.org/AboutTheGC/index.html (last updated Apr. 22, 2013) (the U.N. encourages its vendors to participate in the Global Compact).

${ }^{32}$ Comm. on Human Rights, Sub-Comm. on the Promotion and Protection of Human Rights, Norms on the Responsibilities of Transnational Corporations and Other Business Enterprises with Regard to Human Rights, Aug. 13, 2003, U.N. ESCOR, 55th Sess., U.N. Doc. E/CN.4/Sub.2/2003/12/Rev.2 (Aug. 26, 2013), available at http://www.un.org/en/ga/sea rch/view_doc.asp?symbol=E/CN.4/Sub.2/2003/12/Rev.2.

33 See, e.g., Business Code of Ethics, CoCA-COLA (Jan. 2012), http://www.coca-colafemsa. $\mathrm{com} / \mathrm{femsa} /$ web/arquivos/KOF\%20Business\%20Code\%20of\%20Ethics\%202012.pdf; The Way We Work: Our Global Code of Business Conduct, Rio TiNTo (Dec. 2009), http://www.riotinto. com/documents/The_way_we_work.pdf; Worldwide Code of Conduct, PEPSICO, http://www.pep sico.com/Download/CodeOfConduct/English_09.pdf (last updated Nov. 2008); Code of Business
} 
consultations with the local communities that suffer the adverse consequences of extractive industry activities. ${ }^{34}$

Another approach has involved a variety of home state regulations - these are regulatory approaches taken by the States where companies that have engaged in extractive industries overseas are incorporated. This approach has included using favorable laws to bring suit against extractive companies for violation of human rights, environmental and other laws in their home countries. $^{35}$ For example, Canada enacted a code of conduct for its multinational corporations operating in the mining industry and opened an office to monitor and enforce the code. ${ }^{36}$ The U.S. has enacted a corporate disclosure law that requires companies to disclose any payments to a foreign government for oil, gas or mineral resource extraction in countries like the Democratic Republic of Congo in their annual reports. ${ }^{37}$ This law was successfully challenged in a federal court. ${ }^{38}$ Efforts to enact a similar disclosure forcing law in Australia failed. In June 2011, the U.N. Human Rights Council adopted the "protect, respect and remedy" framework of the Guiding Principles on Business and Human Rights that require states to protect human rights, companies to respect human rights and to offer an opportunity to

Conduct, NESTLÉ (2008), http://www.nestle.com/asset-library/Documents/Library/Documents/C orporate_Governance/Code_of_Business_Conduct_EN.pdf; Code of Conduct, ToTAL, http:// www.total.com/sites/default/files/atoms/file/total-2011-code-of-conduct-en (last visited July 25, 2014).

${ }^{34}$ Ibironke T Odumosu-Ayanu, Governments, Investors and Local Communities: Analysis of a Multi-Actor Investment Contract Framework, 15 MeLB. J. INT'L L. 1, 4 (2014) (discussing multi-actor contracts as agreements among local communities hosting or impacted by a particular investment project and outlining a conceptual framework for an alternative means of ordering in the foreign investment regime).

35 See, e.g., Torture as Tort: Comparative Perspectives on the Development of TransNATIONAL Human Rights Litigation (Craig Scott ed., 2001) (containing essays on the topic).

${ }^{36}$ Building the Canadian Advantage: A Corporate Social Responsibility (CSR) Strategy for the Canadian International Extractive Sector, Foreign AfFaIRS, TRADE AND DEV. CANADA (Mar. 2009), available at http://www.international.gc.ca/trade-agreements-accords-commerciau x/topics-domaines/other-autre/csr-strat-rse-2009.aspx?lang=eng; see also Building the Canadian Advantage-Ottawa's Approach to Corporate Social Responsibility, CAN. Bus. ETHICS Res. NeTwork (Jan. 4, 2013), http://cbernblog.ca/2013/01/building-the-canadian-advantage-ottawasapproach-to-corporate-social-responsibility/ (describing that Canada released a report that "outlined a four-tier approach to ensure that Canadian companies would become the most competitive in international markets based on their ability 'manage social and environmental risks" ").

${ }^{37}$ Dodd-Frank Wall Street Reform and Consumer Protection Act, Pub. L. No. 111-203, 124 Stat. $1376(2010)$.

${ }^{38}$ Nat'l Ass'n of Mfrs. v. S.E.C., 748 F.3d 359, 376 (D.C. Cir. 2014). 
bring grievances and have complaints remedied. ${ }^{39}$ These principles have received favorable reception in the business community. This research project will therefore take into account these Guiding Principles.

\section{THE THIRD PARTY BENEFICIARY PRINCIPLE}

\section{A. Introduction to Third Party Beneficiary Principle}

Under classic contract law, a contract only creates rights for and is binding on the parties to the contract. ${ }^{40}$ Classic contract law tended either to deny the right of a third party beneficiary to enforce a contract, or, at best, to allow enforcement only by third parties who fell within specific, welldefined, and standardized categories - most prominently, third parties to whom the promise owed a preexisting legal obligation. ${ }^{41}$ Courts under the influence of classic contract law applied the doctrines of consideration and privity to object to enforcement by third parties without attempting to provide a social underpinning for that result. ${ }^{42}$ In short, parties must be in privity with one another in order to bring suit on a contract. ${ }^{43}$ This is known as the privity of contract doctrine. ${ }^{44}$ Privity of contract requires that a party bringing suit based on a contract have something to do with the contract such as being the promisee or having some other legal interest in the contract. ${ }^{45}$ The privity of contract doctrine is often invoked to preclude expanding the liability of the promisor of a contract. ${ }^{46}$

However, die-hard adherents of classic contract law doctrine ${ }^{47}$ and many countries around the world are beginning to recognize that a contract can bestow rights on a third party. ${ }^{48}$ Further, as Professor Melvin Eisenberg

\footnotetext{
39 See Ruggie Framework, supra note 22.

40 Second Meeting of the Contact Group for the Drafting of the Standard Material Transfer Agreement, Alnarp, Sweden, April 24-28, 2006, Third Party Beneficiary, Including in the Context of Arbitration, 1 10, CGRFA/IC/CG-SMTA-2/06/Inf.4 (Apr. 2006) [hereinafter U.N. Third Party Beneficiary].

${ }^{41}$ Melvin Aron Eisenberg, Third Party Beneficiaries, 92 Colum. L. ReV. 1358, 1372-73 (1992).

${ }^{42}$ Id. at 1370.

43 See, e.g., Vrooman v. Turner, 69 N.Y. 280, 284 (1877) (“A mere stranger cannot intervene, and claim by action the benefit of a contract between other parties.").

${ }^{44}$ U.N. Third Party Beneficiary, supra note 40, $\uparrow 10$.

${ }^{45}$ Lawrence v. Fox, 20 N.Y. 268, 275 (1859) (Comstock, J., dissenting).

${ }^{46}$ Eisenberg, supra note 41, at 1365.

47 Samuel Williston, Contracts, § 354, at 683 (1920).

48 U.N. Third Party Beneficiary, supra note 40, 11 ; see LAW COMMISSION REPORT, supra note 20, at 1; Contracts (Rights of Third Parties) Act, 1999, c. 31 (UK) [hereinafter C(RTP) Act
} 
argues, there are "strong social reasons" why at least some third party beneficiaries should be allowed to sue on a contract to which he or she is not privy. ${ }^{49}$ Contracts of this sort are referred to as "third party beneficiary" contracts. Here, the beneficiary is classified as either a "creditor beneficiary" 50 or a "donee beneficiary." 51 The third party beneficiary principle, allows a third person, "in his or her own right and name," "enforce a promise made for his or her benefit even though such person is a stranger both to the contract and to the consideration." 53

There are two steps required to determine whether an enforceable third party contract exists. ${ }^{54}$ First, the prerequisites of a third party beneficiary contract must be analyzed, applied, and met; and second, the "varying classes of cases in which a third party has, or may have, an interest in the agreement between two or more parties must be analyzed and differentiated." 55

In order to be a third party beneficiary, the claiming party must show that the contract was entered into by the parties primarily for his or her own benefit. ${ }^{56}$ If it is not clear that the contract was entered into for the benefit of

1999]; see also UNIDROIT Principles of International Commercial Contracts 2004, available at http://www.unidroit.org/english/principles/contracts/principles2004/blackletter2004.pdf.

49 Eisenberg, supra note 41, at 1370.

${ }^{50} \mathrm{Id}$. at 1374 .

51 Id. at 1371. A creditor beneficiary is created when a party owes a legal obligation to a third party prior to a contract being made. See id. The contract is mostly entered into between the contracting parties so that the party that owes the third party the legal duty will be discharged of that duty and the other contracting party promises to perform on behalf of the original promisee. $I d$. For example, prior to the contract $A$ owes $B$ a sum of money, $A$ enters into a contract with $C$ to pay off $A$ 's debt to $B . \quad B$ is the creditor beneficiary. A donee beneficiary of a contract is a third-party to whom the promised beneficial performance comes without cost as a donation or a gift. See 9 Arthur L. Corbin, Corbin on Contracts $\S 42.1$, at 10 (John E. Murray \& Joseph M. Perillo eds., rev. ed. 2007).

52 17A AM. JUR. 2D CONTRACTS $\S 425$.

53 Samule Williston, A Treatise on the Law of Contracts § 37:1, at 9 (Richard A. Lord ed., 4th ed. 2000).

${ }^{54} I d . \S 37.1$, at 16 .

55 Id.

${ }^{56}$ Goossen v. Estate of Standaert, 525 N.W.2d 314, 319 (Ct. App. 1994); see also JoHN Cosgrove McBride \& Thomas J. TOUhey, 8-49 Government Contracts: LAW, Admin. \& Proc. $\S 49.140$ (Walter A.I. Wilson ed.). For example, in Peter Kiewit \& Sons' Co. v. Iowa S. Utilities Corp, a contract between an engineering firm and a public utility to construct a power plant made no mention by name of the ultimate general construction contractor, and contained no expression of any intent to benefit the general contractor. The court held that the general contractor had no standing to sue the engineering firm or the utility for an alleged breach by the engineering firm. 355 F. Supp. 376 (S.D. Iowa 1973). 
a third person, then he or she is merely an incidental beneficiary and cannot recover for a breach of contract. ${ }^{57}$

Under the Third Party Beneficiary Principle, a contract between $A$ and $B$ for $C$ 's benefit gives $C$ standing to sue on such a contract. A third party beneficiary contract arises when a promisor agrees with a promisee that a third party will receive the performance of the contract. ${ }^{58}$ Depending on the jurisdiction, the third party beneficiary principle either eliminates the need for privity or asserts that privity exists, by virtue of the party's status as a third party beneficiary. ${ }^{59}$ Because there is uncertainty and unevenness about the enforcement of third party beneficiary rights, where the third party beneficiary is introduced, it is preferable that a choice of law provision be incorporated to reflect the general understanding of the availability of third party rights. ${ }^{60}$

\section{B. The Evolution of Recognizing Third Party Beneficiary Rights}

The origins of third party beneficiary rights can be traced to English law in the 1677 case, Dutton v. Poole. ${ }^{61}$ Almost a century later, Lord Mansfield reaffirmed the Third Party Beneficiary Principle in Martyn v. Hind ${ }^{62}$ This tendency to allow third parties to bring suit was followed up to the middle of

57 See Century Nat'1 Bank v. Makkar, 751 A.2d 1 (Md. Ct. Spec. App. 2000).

58 Williston, supra note 53, § 37.1, at 12.

59 Id. at $12-13$.

60 See U.N. Third Party Beneficiary, supra note 40, $\uparrow 15$. For example, in a contract the negotiating parties could include a clause that references the UNIDROIT principles of International Commercial Contracts 2004. Id. Such clause could read "general principles of law as reflected in the UNIDROIT Principles of International Commercial Contracts shall be incorporated...." Id.

${ }^{61}$ Dutton v. Pool, (1678) 86 Eng. Rep. 215 (K.B.); see also Gary L. Monserud, Blending the Law of Sales with the Common Law of Third Party Beneficiaries, 39 DuQ. L. REv. 111, 114 (2000). Dutton arose from a family dispute in which a father intended to cut and sell wood in order to raise a dowry for his daughter. Id. The eldest son that was set to inherit the wood objected to his father's intentions and he promised that he would pay his sister a set amount if his father agreed not to sell the wood. Id. When the eldest son's sister was married and his father had died, he refused to pay his sister what he had originally promised his father. $I d$. The sister sued and sought to enforce the promise her brother's promise that was made to her father. Id. The court held that a suit that was based on a promise was not restricted to the person to which the promise was made, but the third party intended to benefit from the promise was allowed to sue in her own name. Id. But see Eisenberg, supra note 41, at 1361. The decision of the court was ambiguous because the Chief Justice decided that, the third party should be able to recover due to the close relationship between the father and child. He suggested that a promise made to the father, could very well be construed as a promise to the daughter.

6298 Eng. Rep. 1174 (K.B. 1776); see also Monserud, supra note 61, at 114. When talking about Dutton v. Poole, Lord Mansfield stated, "it is [a] matter of surprise, how a doubt could have arisen in that case." 98 Eng. Rep. at 1177. 
the nineteenth century in Tweedle $v$. Atkinson, ${ }^{63}$ which reaffirmed the "privity of contract" doctrine and reversed Dutton's recognition of third party beneficiary rights. ${ }^{64}$ In Tweedle, Judge Crompton said, "[it] would be a monstrous proposition to say that a person was a party for the purpose of suing upon [a contract] for his own advantage, and not a party to it for the purpose of being sued." 65 Thus, third party rights fell out of favor with the rise of classic contract theory. ${ }^{66}$

The rise and sudden disappearance of third party rights in England was echoed in Massachusetts; however, the rise and decline occurred in a shorter time period. ${ }^{67}$ Massachusetts followed Dutton and its progeny until at least the early nineteenth century. ${ }^{68}$ Case reports in Massachusetts establish that third party rights were recognized for more than forty years. However in Mellen v. Whipple, ${ }^{69}$ the development of third party rights-like in England-reversed course. ${ }^{70}$ Mellen reaffirmed Tweddle, reaffirming the "privity" doctrine. ${ }^{71}$ Post-Mellen cases did not completely abandon third party beneficiary rights; courts developed more complex exceptions to the "privity" doctrine. ${ }^{72}$ Finally, in 1979, the Supreme Judicial Court in Choate, Hall \& Stewart v. SCA Services, Inc., ${ }^{73}$ reversed Mellen, finding that the "privity" exceptions were becoming too cumbersome. ${ }^{74}$

63121 Eng. Rep. 762 (Q.B. 1861); 1 B. \& S. 393.

${ }^{64}$ Monserud, supra note 61 , at 114.

65121 Eng. Rep. at 764.

${ }^{66}$ Monserud, supra note 61, at 115.

67 Id.

${ }^{68}$ See id. The first major case in Massachusetts was Felton v. Dickinson, 10 Mass. 287 (1813). In that case, Felton was a fourteen-year-old boy that was put into the service of Dickinson, who promised the boy's father that he would support the boy until he turned twenty-one, whereby at that time he would either pay the boy $\$ 200$ or give him a parcel of land in Vermont, whichever he elected. Id. When the boy turned twenty-one, Dickinson failed to pay him on his election as promised, the boy sued on the promise made to his father. Id. He won a judgment at the trial court and the Supreme Judicial Court sustained the judgment on the basis of Dutton v. Poole. Felton, 10 Mass. at 289.

6967 Mass. 317 (1854).

70 See Monserud, supra note 61 , at $115-16$.

71 Mellen, 67 Mass. at 321. The court noted specifically that, "[t]here must be a privity of contract between the plaintiff and defendant, in order to render the defendant liable to an action, by the plaintiff, on the contract." Id.

72 See Monserud, supra note 61, at 117.

73378 Mass. 535 (1979).

74 See Monserud, supra note 61, at 117. Notably, Monserud observes that during the Mellen era, other American jurisdictions recognized third party rights on contracts either through case law or by statute. $I d$. 
The recognition of third party rights was anchored in New York. ${ }^{75}$ New York's 1859 decision, Lawrence v. Fox ${ }^{76}$ gradually became the paradigmatic American case allowing third party recovery for creditor beneficiaries. ${ }^{77}$ Lawrence v. Fox is celebrated today as a landmark case that established third party recovery on contracts. ${ }^{78}$ However, it was not remarkably enlightening for its time, because at the time, New York permitted third party beneficiaries to bring suit on a contract to which they were not privy. ${ }^{79}$ Lawrence's notoriety arose not out of its holdings, but instead out of the clarity of its several opinions. ${ }^{80}$

New York cases continued to reaffirm third party rights. For example, about half a century later, Seaver v. Ransom ${ }^{81}$ recreated Dutton's donee beneficiary principle. ${ }^{82}$ New York courts recognized two classifications of third party beneficiaries. ${ }^{83}$ Notably, and as discussed later, this two-part classification was mirrored in the First and Second Restatements of the Law of Contracts. Even though New York courts regularly recognized third party rights, the development of this area of law may not have been possible had it

75 See id.

7620 N.Y. 268 (1859). In the case, Holly loaned Fox \$300. Id. at 269. At the time of the loan, Holly informed Fox that he owed the same amount of the loan to Lawrence. Id. Fox promised Holly, but did not directly promise Lawrence, that he would repay Holly's debt to Lawrence. $I d$. at 271. The majority of the Court (6-2 decision) agreed that Lawrence had a case against Fox. The court noted that:

In this case [Fox], upon ample consideration received from Holly, promised Holly to pay his debt to [Lawrence]; the consideration received and the promise to Holly made it as plainly his duty to pay [Lawrence] as if the money had been remitted to him for that purpose, and as well implied a promise to do so as if he had been made a trustee of property to be converted Id. at 274. into cash with which to pay.

${ }_{77}$ See Monserud, supra note 61, at 117-18.

78 See Eisenberg, supra note 41, at 1363.

${ }^{79}$ Monserud, supra note 61, at 118.

80 Samuel Williston and other casebook editors were impressed with the clarity of the opinions; consequently Lawrence v. Fox became a leading case for contracts casebooks. Eisenberg, supra note 41, at 1363; Monserud, supra note 61, at 118.

81120 N.E. 639 (N.Y. 1918). Mrs. Beman objected to the will her husband, Judge Beman had drafted for her because her niece was not accommodated by the will as she had wanted. Id. She was dying and instead of writing a new will Judge Beman promised that if Mrs. Bemen would sign her will, he would accommodate for her niece in his will. Id. When Judge Beman died, his will did not accommodate for Mrs. Beman's niece as the judge had promised. $I d$. at 640 . The niece sued the executors of Judge Beman's estate and the New York Court of Appeals upheld her right to recover. Id. at 640-42.

${ }_{82}$ See Monserud, supra note 61, at 118.

${ }^{83} \mathrm{Id}$. 
not been for Professors Samuel Williston and Arthur Corbin, and even more of the legal realists of later years. ${ }^{84}$

\section{The First Restatement of the Law of Contracts}

The First Restatement of Contracts initiated the modern law of third party beneficiaries by pushing aside the doctrinal objections to enforcement by third parties and by moving from a rule-based body of third party beneficiary law to a body of law supported by a general principle rooted in social equity. ${ }^{85}$ The First Restatement recognized third party rights explicitly in Section $133 .^{86}$ As recognized in this section, the traditional analysis categorizes third parties as donee beneficiaries, creditor beneficiaries, or incidental beneficiaries. ${ }^{87}$ The terminology of the First Restatement is based on terminology from Dutton v. Poole and Lawrence v. Fox. ${ }^{88}$ The establishment of a donee beneficiary resulting from the opinion of Dutton $v$. Poole was written into subsection (a) of Section $133 .{ }^{89}$ The creation of a creditor beneficiary resulting from Lawrence $v$. Fox was incorporated into Section 133(b). ${ }^{90}$ Finally, incidental beneficiaries - third parties that benefit from performance of the contract but do not have enforceable rights-are referred to in Section 133(c). Sections 135 and 136 provided that a donee or

\footnotetext{
${ }^{84}$ Id. Williston wrote an article for the Harvard Law Review in 1902 that examined how third party rights were assessed at the turn of the nineteenth century. Samuel Williston, Contracts for the Benefit of a Third Person, 15 HARV. L. REV. 767 (1902). The privity of contracts doctrine was based on the will theory of contracts that was very prevalent before the twentieth century. As Roscoe Pound noted, American courts began declining to take privity seriously in the early part of the twentieth century. Roscoe Pound, The Rise of the Will in Law, 68 HARV. L. ReV. 6 (1954). For a full review of importance of legal realism and the breakdown of classic contract law based on the will theory, see Karl E. Klare, Contracts Jurisprudence and the First-Year Casebook, 54 N.Y.U. L. REV. 876 (1979) (reviewing Charles L. Knapp, Problems in Contract Law: Cases and Material (1976)).

${ }^{85}$ See Eisenberg, supra note 41 , at $1374-76$. Suppose $C$ is an intended beneficiary of a contract between $A$ and $B$. $A$ breaches the contract with $B$ to the extent that $C$ suffers from $A$ 's breach. It is equitable to allow $C$ to bring a suit in order to recover damages to the extent that he has suffered.

86 Restatement of CONTRACTS $§ 133$ (1932).

${ }^{87}$ See CORBIN, supra note $51, \S 44.3$, at 52.

88 John D. Calamari \& Joseph M. Perillo, The Law of Contracts $\S 17.1$, at 642 (4th ed. 1998).

89 See supra note 61; RestatemENT OF CONTRACTS $§ 133($ a) (1932).

90 See supra note 76 and accompanying text.
} 
a creditor beneficiary had legally enforceable rights under a contract, but an incidental beneficiary did not. ${ }^{91}$

The First Restatement focuses the classification of beneficiaries on the purpose of the promise that the promisor made to the promisee. ${ }^{92}$ As mentioned above, the three categories of beneficiaries are donee, creditor, and incidental. The third party is a donee beneficiary if the purpose of the promisor was to confer a gift on the promisee; a creditor beneficiary if the purpose of the promisee in obtaining the promise was to discharge a preexisting legal obligation owed to the beneficiary by the promisee; and an incidental beneficiary if he will benefit from the performance of the contract, but does not satisfy the criteria of the other two categories. ${ }^{93}$ Even though the First Restatement recognizes third party beneficiary rights, its focus on the purpose (of the contract) and the surrounding language is confusing and provides "no guidance [concerning] the critical question of how a court was to determine whether the relevant purpose was present." 94

To avoid the ambiguity of the terminology in Section 133, many courts have expressed an "intent to benefit" test. ${ }^{95}$ This test requires that intent to benefit a third party be clear. ${ }^{96}$ The test varied between states; some states required that intent be clear, while others required it to be express or definite. $^{97}$ Therefore, the application of the "intent to benefit" test was somewhat ambiguous, at least between jurisdictions.

Professor Eisenberg also criticized the "intent to benefit" test because the term "intent" itself is ambiguous. "One of the fundamental disputes concerning the 'intent to benefit' test is whether both the promisor and promisee must intend to benefit the third party, or whether the promisee's

91 See Restatement of CONTRACTS, $\S$ 135-136 (1932) (implying that third party beneficiaries do not have enforceable rights).

${ }_{92}$ CAlamari \& Perillo, supra note 88, § 17.2, at 643.

${ }_{93} I d$.

94 Eisenberg, supra note 41, at 1377.

95 CAlamari \& Perillo, supra note 88, § 17.3, at 643.

96 Eisenberg, supra note 41, at 1379.

${ }^{97}$ Id. Eisenberg cites several cases that applied the "intent to benefit rule." Those cases are Security Mut. Cas. Co. v. Pacura, 402 So. 2d 1266, 1267 (Fla. Dist. Ct. App. 1981) (requiring that intent to benefit must be "clear"); Donalson v. Coca-Cola Co., 298 S.E.2d 25, 27 (Ga. Ct. App. 1982) (requiring intent be clear); Khabbaz v. Swartz, 319 N.W.2d 279, 285 (Iowa 1982) (requiring that intent to benefit must be "express"); Snyder Plumbing \& Heating Corp. $v$. Purcell, 9 A.D.2d 505, 507 (N.Y. App. Div. 1960) (requiring clear intent); Keel v. Titan Constr. Corp., 639 P.2d 1228, 1231 (Okla. 1981) (requiring express intent); Kelley Health Care, Inc. v. Prudential Health Ins. Co. of Am., 309 S.E.2d 305, 307 (Va. 1983) (requiring definite intent).

98 See Eisenberg, supra note 41, at 1378. 
intention should govern." 99 As illustrated, even the test that courts use to avoid the ambiguities of the First Restatement is itself riddled with ambiguities. Even though the First Restatement's terminology and tests that recognize third party rights may be confusing and ambiguous, they nevertheless clarify the scope of third party beneficiary rights that have become unclear after the First Restatement. ${ }^{100}$

\section{The Second Restatement of the Law of Contracts}

The Second Restatement greatly expanded third party rights, recognizing third party beneficiary rights from Sections 302 to $315 .^{101}$ However, the heart of its third party beneficiary recognition is Section 302. ${ }^{102}$ The Second Restatement provides that a person is a beneficiary of a contract where a "recognition of a right to performance in the beneficiary is appropriate to effectuate the intentions of the parties." 103 However, this requirement is qualified, because there does not need to be such recognition where it is "otherwise agreed between the promisor and promisee." 104 Thus, the Second Restatement makes clear that the general common law view is that parties to a contract may set whatever terms they deem desirable for the effectuation of their agreement, which the courts must recognize and uphold. ${ }^{105}$

In some instances, courts establish a distinction between incidental/indirect beneficiaries and direct beneficiaries. Only direct beneficiaries may be

\footnotetext{
99 CoRBIN, supra note 51, $\$ 44.1$, at 46.

100 See Monserud, supra note 61, at 122 (suggesting that Section 133 and related sections helped remove the stigma of recognizing third party rights and may have helped to "firmly root" third party rights in American contract law). Under the First Restatement, it had become apparent that a number of third party beneficiaries did not fall within the "donee" and "creditor" categories, such that some courts simply disregarded the categorization approach and allowed beneficiaries who were neither creditors nor donees to recover. The inflexibility of the categorization approach led to changes in the Second Restatement of Contracts, under which intended beneficiaries, who can enforce contracts, are contrasted with incidental beneficiaries, who cannot. Section 133 of the First Restatement opened the eyes of several jurisdictions to the rights of third parties. Many took issue with how narrow Section 133 was and wished to expand it. Section 133 of the First Restatement was therefore the first step in recognizing third parties as beneficiaries.

101 See ReStatement (SECOND) OF CONTRACTS $§ 302-15$ (1981).

102 CORBIN, supra note $51, \S 44.4$, at 55.

103 Restatement (SECOND) OF CONTRACTS § 302(1) (1981).

104 Id.

105 See Salt River Project Agric. Improvement \& Power Dist. v. Westinghouse Elec. Corp., 694 P.2d 198, 206 (Ariz. 1984) ("A basic policy of contract law . . . is to preserve freedom of contract and thus promote the free flow of commerce.").
} 
recognized as a third party beneficiary. ${ }^{106}$ However, the determination must take into account the relevant law and facts. ${ }^{107}$

\section{E. Modern Application of Third Party Beneficiary Principle in the United States}

Due to the evolution of the common law and the Restatements' recognition of third party rights, third party rights have been recognized in a wide variety of legal contexts. ${ }^{108}$ In the context of government contracts, the Third Party Beneficiary Principle seems to have been first applied in Maneely v. United States. ${ }^{109}$ In Maneely, a decision barring a third party's claim where there was no privity was reversed because the third party benefitted from the transaction. ${ }^{110}$

In terms of government contracts, when a governmental entity contracts with a party, the citizens of the governmental entity's jurisdiction are deemed to be third party beneficiaries to that contract. ${ }^{111}$ Courts have held that the essential element for third party beneficiary status is the intention of the

\footnotetext{
106 Schuerman v. United States, 30 Fed. Cl. 420, 433 (1994) ("The court carefully must distinguish between incidental and indirect beneficiaries and direct beneficiaries, only the latter of which qualifies for third-party beneficiary status."). In the context of government contracts, see GECCMC 2005-C1 Plummer St. Office Ltd. P'ship v. JPMorgan Chase Bank, Nat. Ass'n, 671 F.3d 1027, 1033 (9th Cir. 2012) (citing Cnty. of Santa Clara v. Astra USA, Inc., 588 F.3d 1237, 1244 (9th Cir. 2009) ("Parties that benefit from a government contract are generally assumed to be incidental beneficiaries," rather than intended beneficiaries, and so "may not enforce the contract absent a clear intent to the contrary")).

${ }^{107}$ Glass v. United States, 258 F.3d 1349, 1353 (Fed. Cir. 2001), amended on reh'g, 273 F.3d 1072 (Fed. Cir. 2001) (stating that whether plaintiff is a third party beneficiary "is a mixed question of law and fact").

108 See Joyner v. Vitale, 926 P.2d 1154, 1157 (Alaska 1996) (explaining that, in the context of a mortgage, when a purchaser assumes a mortgage third party beneficiary law is invoked); Acoustics v. Hanover Ins. Co., 287 A.2d 482, 485 (N.J. Super. Ct. Law Div. 1971) (holding that a subcontractor is a third party beneficiary of a performance bond between the owner, contractor, and surety); Wilson v. Oliver Costich Co., 247 N.Y.S 131, 134 (App. Div. 1931) (holding that a non-inhabitant of the political unit in controversy may qualify as a third party beneficiary).

10968 Ct. Cl. 623 (1929); see also Government ConTRACTs: LAw, AdMIN. \& PROC. $\$ 49.10$ (2015). In Maneely, the Government entered into a cost-type contract, one provision was, if the contract was terminated, the contracting officer would assume and become liable for all unliquidated claims incurred by the contractor. After the plaintiffs supplied the material, the contract was terminated. The plaintiff filed a claim, but it was disallowed because there was not privity of contract between the plaintiffs and the Government. The disallowance was reversed on the third party beneficiary theory.

${ }^{110}$ Maneely, $68 \mathrm{Ct}$. Cl. at 629. Interestingly, Maneely applied a test similar to the "intent to benefit" test, citing Vrooman v. Turner, 69 N.Y. 280, 283-84 (1877).

111 See Eisenberg, supra note 41, at 1406 ("The courts have tended to give suits by thirdparty beneficiaries under government contracts special or 'categorical' treatment.").
} 
parties for the contract to benefit the third party. ${ }^{12}$ Even the Second Restatement recognizes liability for a party that contracts with a governmental entity, but only if the contract expressly creates a cause of action for the third party citizens or where such a suit would be consistent with the terms of the contract and the policy of law authorizing the contract. $^{113}$ Some states, such as New York, do not even require that the contract expressly create a cause of action for the citizens, allowing a cause of action to stand where the contract is intended to benefit the individual citizens of that governmental entity. ${ }^{114}$

The Third Party Beneficiary Principle has been applied in various other types of cases, such as construction contract cases involving bonds and suretyships. One such situation is when an owner of property contracts with the general contractor and requires the general contractor to put up a payment bond to ensure payment to any subcontractors. These subcontractors may be third party beneficiaries to the contract between the owner and the general contractor. ${ }^{15}$

While these construction cases do not uniformly allow the subcontractor to enforce the promise within the contract between the owner and the general contractor, this disparity in the case law can be attributed to the special circumstances of the construction relationship because the subcontractor

\footnotetext{
112 Montana v. United States, 124 F.3d 1269, 1273 (Fed. Cir. 1997) (implying a party is a third-party beneficiary of a contract with the Government if that contract "reflect[s] the express or implied intention of the parties to benefit the third-party" (quoting Schuerman v. United States, 30 Fed. Cl. 420, 433 (1994))).

113 See Restatement (SECOND) OF CONTRACTS $§ 313(2)$ (1981).

114 See Pond v. New Rochelle Water Co., 76 N.E. 211, 214 (N.Y. 1906) (holding that the municipality contracted with the corporation "to protect [the municipality's] inhabitants," so those inhabitants were third party beneficiaries of the contract); Seaver v. Ransom, 224 N.Y. 233, 238 ("The right of the third party is . . . upheld in . . the public contract cases where the municipality seeks to protect its inhabitants by covenants for their benefit ...." (internal citations omitted)).

${ }^{115}$ See, e.g., Eisenberg, supra note 41, at 1397 ("[T] he modern tendency is to allow subcontractors to recover against the sureties of payment bonds in ... private . . cases."); Daniel-Morris Co. v. Glens Falls Indem. Co., 126 N.E.2d 750, 752 (N.Y. 1955) (finding that the primary purpose of the payment-performance bond taken out by the general contractor was to ensure payment to material men because the underlying contract required the subcontractor to furnish its work "free of the lien of any third party . .."); Jacobs Assocs. v. Argonaut Ins. Co., 580 P.2d 529, 532 (Or. 1978) (finding that a subcontractor could collect payment from a surety when the general contractor defaulted in payment due to insolvency because "the bond was for the benefit of unpaid creditors ..."). But see Fosmire v. Nat'l Surety Co., 127 N.E. 472,473 (N.Y. 1920) (finding that a laborer could not recover unpaid wages from the surety under a payment-performance bond required by the Highway Law for a public works contract because "[t]he dominant purpose of this bond was protection to the state").
} 
generally has the right to place a lien on the owner's property if the general contractor fails to pay the subcontractor for the work performed. ${ }^{116}$

\section{F. Evolution of the Third Party Beneficiary Principle Abroad}

Like the United States, the United Kingdom and France have begun to recognize third party beneficiary rights, ${ }^{117}$ even though their paths to recognition may have taken indirect routes. ${ }^{118}$ In the United Kingdom, the Law Commission recommended the recognition of a third party beneficiary law in its report of $1996 .{ }^{119}$ Law Commission Report 242 led to a bill that was enacted as the Contracts (Rights of Third Parties) Act 1999. ${ }^{120}$ The Contracts Act of 1999 allows a third party to enforce contracts that expressly provide for enforcement by a third party, and also permits the enforcement of contracts whose terms purport to confer a benefit upon a third party. ${ }^{121}$ Unless parties explicitly agree otherwise, the Act does not apply to contracts entered into before May 11, 2000. ${ }^{122}$ According to the Commission, the Third Party Beneficiary Principle ${ }^{123}$ causes "difficulties in commercial life."124 For example, in insurance contracts, there are some areas where the legislature did not intervene "to give third party beneficiaries a right to enforce the contract against the insurer." 125 The Commission mentioned the

\footnotetext{
116 See N.Y. LiEn LAw § 3 (McKinney 2013).

117 See, e.g., James M. Hosking, The Third Party Non-Signatory's Ability to Compel International Commercial Arbitration: Doing Justice Without Destroying Consent, 4 PEPP. DisP. RESOL. L.J. 469, 527 (2004) ("The trend in all three jurisdictions is towards greater recognition of third party beneficiary rights and application of a test which has at its touchstone the 'intention' of the parties.").

118 See, e.g., Howard O. HunTER, Modern Law OF CONTRACTS $§ 20: 4$ (2013) (noting that "[t]he major inroads on the privity doctrine have come from collateral attacks such as actions premised on unjust enrichment, tort, or the law of trusts").

119 See Law Commission Report, supra note 20, at 50. The Act came into force on November 11, 1999.

${ }^{120}$ C(RTP) Act 1999, supra note 48.

121 Rizyan Khawar, Reinsurance and Privity in the Past, Present, and Future: Privity of Contract in Reinsurance and the Contracts (Rights of Third Parties) Act of 1999, 77 TuL. L. REV. 495, 499 (2002). The intention of the parties is crucial to determine if the third party has privity of contract. To be considered a third party beneficiary, the third party must be identified in the contract. The C(RTP) Act of 1999 is very liberal in its determination of what constitutes identification. A party can be identified by name, as a member of a class, or by answering a particular description. Id.

${ }_{122}$ C(RTP) Act 1999, supra note 48, § 10.

123 See LAW COMmission RePORT, supra note 20, at 1 ("[A] contract does not confer rights on someone who is not a party to the contract.").

124 Id. at 43 .

125 Id. at 48 .
} 
situation where an employer can take out medical expenses insurance for its employees without there being doubts as to whether the employees can enforce the policy against the insurance company. ${ }^{126}$

In France, third-party beneficiary rights are not the rule but an exception to the principle stated in Article 1165 of the French Civil Code. Article 1165 provides that: "Agreements produce effect only between the contracting parties; they do not harm a third party, and they benefit him only in the case provided for in Article 1121." " effect only between the contracting parties"128 is called in French law "effet relatif du contrat," literally, the relative effect of a contract. It offers a strict reading of the privity of contract doctrine. Article 1121 of the French Civil Code states that:

One may likewise stipulate for the benefit of a third party ["stipuler au profit d'un tiers"], where it is the condition of a stipulation which one makes for oneself or of a gift which one makes to another. He who made that stipulation may no longer revoke it, where the third party declares that he wishes to take advantage of it. ${ }^{129}$

This exception is fairly narrow and limited to those two situations: "the condition of a stipulation which one makes for oneself or of a gift which one makes to another."130 Nonetheless, French courts have adopted a flexible approach that seems to be closer to the modern reality of contracts. ${ }^{131}$ The highest French civil court (the Cour de Cassation) used the concept of group of contracts to allow for remedies for parties who were not parties the initial contract. ${ }^{132}$ This concept joins contracts that are "mutually linked

\footnotetext{
${ }^{126} I d$. at $48-49$.

127 Code Civil [C. CIV.] art. 1165 (Fr.), English translation, available at http://www.legifr ance.gouv.fr/Traductions/en-English/Legifrance-translations.

${ }^{128} \mathrm{Id}$.

129 Code Civil [C. CIV.] art. 1121 (Fr.), English translation, available at http://www.legifran ce.gouv.fr/Traductions/en-English/Legifrance-translations.

131 See, e.g., Mitchel de S.-O.-l'E. Lasser, Judicial (Self-) Portraits: Judicial Discourse in the French Legal System, 104 YALE L.J. 1325, 1386-87 (1995) ("It is true that Article 1165 was better adapted to an individualist civilization than to the social and economic relations of our time, and that it becomes more and more difficult to consider contracts in an isolated fashion.").

${ }^{132}$ Cour de cassation [Cass.] [supreme court for judicial matters] lère civ., June 211988 , Bull. Civ. I, No. 85-12.609 (Fr.) 5, note C. Larroumet, comments of P. Jourdain, Rev. trim. dr. civil 1988, 762 and Ph. Remy, eod.loc. 1989, 107.
} 
contracts."133 However, the mechanism of Article 1121 of "stipulation pour autrui" (third party beneficiary contract) still necessarily implies some sort of relationship between the stipulator and the beneficiary.

\section{BASIS OF THIRD PARTY LEGAL INTERESTS IN RESOURCE CONTRACTS}

In this Part of the Article, I advance four reasons why the Third Party Beneficiary Rule applies to resource extraction contracts. The first and most important one is that third party beneficiary status is consistent with the wishes of the promisee and promisor in resource contracts and second that resource contracts are made for the benefit of the public. Third, I argue in favor of the principle on grounds of justice and morality, and fourth on public policy grounds.

\section{A. Consistency Between Wishes of Contracting Parties and Third Party Beneficiaries}

Third party beneficiary status is consistent with the promises made between contracting parties in resource extraction contracts. ${ }^{134}$ In other words, allowing third parties to sue is necessary to effectuate the intentions of the parties to the contract. Thus, the ability to sue on the part of a third party here is remedial, rather than substantive. ${ }^{135}$ It is remedial because the third party would be seeking to enforce the promises made between the contracting parties. Here, standing for the third party would not necessarily depend on proving that the contracting parties intended to benefit the third party. However, it is beyond doubt as this section will show, that natural resource contracts are intended for the benefit of the nationals and local peoples of the country where the resources are located.

Although governments contract with investors as if natural resource extraction agreements are private contracts, they aim at producing public benefits and their proceeds are intended to benefit the public. In many legal systems around the world, mineral resources and other resources such as water and lands are vested in States, however, the rights of the States to use

\footnotetext{
133 Denis Tallon, The Principle of the Relative Effect of Contracts and the Theory of Groups of Contracts: Towards A New Reading of Article 1165 of the French Civil Code?, 6/7 TuL. Civ. L.F. 95, 97 (1991-1992).

${ }_{134}$ See Eisenberg, supra note 41, at 1386.

${ }^{135} I d$.
} 
and dispose of these resources is understood to be limited if it would cause a substantial impairment to the interests of the public in such resources. ${ }^{136}$

This principle is further reflected in many national Constitutions, which treat natural resources, not as market goods, but as public goods in which the national population has a direct interest. The Egyptian Constitution, for example, declares that natural resources "belong to the people," and that the people are "entitled to their revenues." 137 The Constitution further provides that the Egyptian state "is committed to preserving such resources for future generations and putting them to good use."138 The Ghanaian Constitution similarly vests all minerals on its territory, lakes, territorial sea, and continental shelf "in the President on behalf of, and in trust for the people of Ghana." 139 The Iraqi Constitution provides that "oil and gas are owned by all the people of Iraq in all the regions and governates." 140 The 2010 Kenyan Constitution provides in part that its citizens have a right to "secure ecologically sustainable development and use of natural resources while promoting economic and social development." ${ }^{\text {"141 }}$ In short, governments globally argue they need private investors, because private investors supply

\footnotetext{
${ }^{136}$ For example, in the United States, the public trust doctrine limits government's use of land. In Ill. Cent. R.R. Co. v. Illinois, 146 U.S. 387 (1892), the Supreme Court held that though the state may own certain public land (Lake Michigan), its title to that land was different from lands intended for sale; it was "a title held in trust for the people of the state that they may enjoy the navigation of the waters, carry on commerce over them, and have liberty of fishing therein freed from the obstruction or interference of private parties." Id. at 452. In 1970, Professor Joseph Sax argued that the public trust doctrine applies also to environmental issues. Danielle Spiegel, Note, Can The Public Trust Doctrine Save Western Groundwater?, 18 N.Y.U. ENVTL. L.J. 412, 429 (2010) (citing Joseph Sax, The Public Trust Doctrine in Natural Resource Law: Effective Judicial Intervention, 68 Mich. L. REV. 471, 556 (1970)). Even the Supreme Court has held that states should not have complete control over their natural resources. In Pennsylvania v. West Virginia, 262 U.S. 553 (1923), the Supreme Court noted that if states could control their natural resources, "a singular situation might result: Pennsylvania might keep its coal, the Northwest its timber, and the mining states their minerals." Id. at 599.

Since the 1970s, the public trust doctrine has been adopted in nations across the world. For example, the Supreme Court of India held:

Our legal system - based on English common law-includes the public trust doctrine as part of its jurisprudence. The state is the trustee of all natural resources which are by nature meant for public use and enjoyment. Public at large is the beneficiary of the sea-short, running waters, airs, forests and ecologically fragile lands. The state as a trustee is under a legal duty to protect the natural resources.

M.C. Mehta v. Kamal Nath, (1997) 1 S.C.C. 388, 388 (India).

${ }_{137}$ Constitution of the Arab Republic OF Egypt, Sept. 11, 1971, art.18.

${ }_{138}$ Id.

139 Constitution of the Republic of GHanA, art. 257(6).

140 Doustour Joumhouriat AL-IraQ [COnStitution], 2005, art. 111 (Iraq).

141 Constitution, 2010, art. 30 (Kenya).
} 
skills and technology to extract the natural resources that the governments own on behalf of their people.

Investors also come with financial resources to pay for the extraction of natural resources that governments argue they need to extract to benefit the public. These financial resources are in turn applied towards public projects, such as roads, or for paying for public education and health. According to the African Natural Resources Center of the African Development Bank, African countries have about $30 \%$ of the world's known reserves of minerals; about $8 \%-10 \%$ of gas resources; and the largest reserves of cobalt, diamonds, platinum, and uranium. ${ }^{142}$ Ideally, investors would be able to turn these resources into income for the citizens of African countries, fostering economic growth and fortitude while benefiting their shareholders with higher profit.

In an attempt to ensure these benefits inure to governments with extractive resources the private sector created the Extractive Industry Transparency Initiative. ${ }^{143}$ This global coalition is predicated on the view that the wealth generated from natural resources should be "an important engine for sustainable economic growth" that results in poverty reduction and that such wealth should be used in the interest of national development. ${ }^{144}$ This and similar initiatives recognize the use of natural resources to benefit the populations in the countries where extraction happens.

Another group that has attempted to protect the interests of local communities is the World Bank. The World Bank, one of the largest lenders of development finance to countries with large mineral deposits, established the World Bank Inspection Panel in 1993. ${ }^{145}$ The purpose of the Inspection Panel is to give people affected by World Bank-funded projects the right to bring to the Bank's attention for corrective action adverse social and environmental impacts of Bank financed projects. ${ }^{146}$ The Inspection Panel undertakes this mandate by examining those social and economic impacts and ensuring the Bank follows appropriate operation policies and procedures. ${ }^{147}$ There are safeguards among the Bank's operational policies and procedures to protect the environment,

\footnotetext{
${ }^{142}$ Africa's Natural Resources: A Snap Shot, AfriCAN NATURAL Res. Ctr., available at http://www.afdb.org/en/topics-and-sectors/initiatives-partnerships/african-natural-resources-ce nter-anrc/ (last visited May 19, 2015).

${ }^{143}$ The EITI Principles, EXTRACTIVE Indus. TransParency InItIATIVE, http://eiti.org/eiti/ principles (last visited July 31, 2014); EITI Countries, EXTRACTIVE INDUS. TRANSPARENCY INITIATIVE, http://eiti.org/countries (last visited July 31, 2014).

${ }_{144}$ The EITI Principles, supra note 143, $\mathbf{\uparrow} 1$ 1-2.

145 The Inspection Panel, WorLD BANK, http://ewebapps.worldbank.org/apps/ip/Pages/Abo utUs.aspx (last visited Aug. 3, 2014).

${ }^{146} \mathrm{Id}$.

${ }^{147} I d$.
} 
including forests, as well as indigenous peoples and their cultural resources. ${ }^{148}$ Noncompliance can lead to dire results. For example, the World Bank withdrew support of the Chad-Cameroon Pipeline project as a result of non-observance of its operational policies and procedures. ${ }^{149}$

\section{B. Resource Development Should Benefit Local Citizens}

Among the most basic and universal principles of resource development is that it "should secure the greatest benefit for citizens." 150 In many lowincome, resource-rich countries, natural resources form a substantial part of the wealth of the country. ${ }^{151}$ Many of these countries depend on these resources to earn revenue to support their national budgetary needs to finance education, health, food, water, and other essential programs. The revenue from these resources is also the only reliable source of funding for long-term investments like infrastructure. ${ }^{152}$ Therefore, development in general, including resource extraction, should be done primarily to benefit the people. ${ }^{153}$ However, there is often a divergence between theory and practice

${ }^{148} I d$.

149 World Bank Pulls Out of Chad-Cameroon Oil Pipeline Project, EcON. Times (Sept. 10, 2008, 5:44 AM), http://articles.economictimes.indiatimes.com/2008-09-10/news/27732853_1 chad-cameroon-chadian-government-pipeline-project.

${ }^{150}$ The Twelve Precepts, NAT. RESOURCE CHARTER, http://naturalresourcecharter.org/precepts (last visited Aug. 3, 2014). Indeed, in August 2014, the South African Development Community (SADC) will hold its annual summit in Zimbabwe, where it will focus on methods by which African countries can maximize the benefits of their natural resources. Sean Woolfrey, Beneficiation in SADC, TRALAC (Aug. 13, 2014), http://www.tralac.org/discussions/article/60 46-beneficiation-in-sadc.html?utm_source $=$ Weekly+tralac + Newsletter\&utm_campaign $=3$ ba006 fd0d-NL20140813\&utm_medium=email\&utm_term=0_a95cb1d7ad-3ba006fd0d-269805525. This summit will follow efforts by many African nations to benefit local economies. Id. For example, in 2012, South Africa adopted a "Beneficiation Strategy" to promote industrialization. Id. Botswana has taken steps to process locally mined diamonds. Id. Further, Zambia has raised taxes on mining companies and has introduced a "windfall tax" for high profits. Id.

${ }^{151}$ See infra Figure 1 (conveying that the percentage of natural capital in the wealth of lowincome countries is greater than in middle and high-income countries).

${ }^{152}$ Naazneen H. Barma, Kai Kaiser, Tuan Minh Le \& Lorena Vinuela, Rents to Riches? The Political Economy of Natural Resource-Led Development, WORLD BANK 78 (2012), available at https://openknowledge.worldbank.org/bitstream/handle/10986/2381/659570PUB0EPI1073 7B0Rents0to0Riches.pdf? sequence=1.

${ }_{153}$ Professor Epstein notes that typically, the terms of the contract must directly provide for liability to the third party; this heightened standard is justified by the fact that these contracts are made to benefit third parties. Epstein, supra note 19, at 2256-57. So, the intended benefit to third parties ends up reducing their ability to sue. Id. at 2257. Based on the fact that citizens are often harmed by resource extraction contracts, this fact seems a bit ironic. 
as evidenced by many examples of situations where citizens of countries rich in natural resources are deprived of their benefits. ${ }^{154}$

Despite these problems with resource contracts, many groups have instituted policies to help citizens in resource contract situations. The U.N. formally recognized that resource contracts should benefit citizens in its 1986 Declaration on the Right to Development. ${ }^{155}$ This Declaration provides that "the human person is the central subject of the development process and that development policy should therefore make the human being the main participant and beneficiary of development."156 Further, the Declaration makes the right to development "an inalienable human right," which implies that citizens have the right to "full sovereignty over all their natural wealth and resources." In In addition, the Declaration puts the onus on States, giving them the "duty to formulate appropriate national development policies" that aim to improve the well-being of the entire population, resulting in the "fair distribution of [development] benefits." 158

The importance and recognition of the right to development is reflected in subsequent U.N. resolutions, the African Charter on Human and Peoples' Rights, discussed below, and the U.N. Millennium Declaration. ${ }^{159}$ The

\footnotetext{
154 Though these agreements should be made to benefit the citizens of resource-rich nations, the reality is that income generated from these agreements often falls into the hands of the affluent parties who trade these resources. Thomas W. Pogge, Eradicating Systemic Poverty: Brief for a Global Resources Dividend, 2 J. Human Dev. 59, 64 (2001). Pogge notes, "[t]he global poor get to share the burdens resulting from the degradation of our natural environment while having to watch helplessly as the affluent distribute the planet's abundant natural wealth amongst themselves." Id. Additionally, foreign investors have engaged in practices that, while purporting to help local communities, actually harm those communities. For example, the practice of "land grabs"- purchasing enormous amounts of land for farming - is said to benefit local communities. Steve Baragona, UN: 'Land Grab' Deals Hurt Local Farmers, VoICE OF AM. News (Dec. 7, 2012, 1:08 PM), http://www.voanews.com/content/un-reportland-grab-deals-hurt-locals/1560599.html. However, in Ethiopia, foreign companies have spent over \$2 billion leasing over 225,000 hectares of land for farming, but the harvests are exported back to the investors' home countries. Id. Thus, fertile land that could produce food for local communities is instead used to supply food to already wealthy countries. Id. In countries like Ethiopia that already face severe food shortages, this practice is extremely detrimental. Id. To make matters worse, local communities allege that money that should have gone to the communities has instead fallen into the pockets of corrupt governments. Id

155 Declaration on the Right to Development, G.A. Res. 41/128, U.N. Doc. A/RES/41/128 (Dec. 4, 1986).

${ }^{156}$ Id.

157 Id. art. 1.

158 Id. art. 2(3).

159 James Thuo Gathii, The Cotonou Agreement and Economic Partnership Agreements, in U.N. Human Rights, OfFice of the High COMm'R, ReAlizing the Right to Development 259, 260 (2013).
} 
Millennium Declaration, adopted during the Millennium Summit in September $2000,{ }^{160}$ makes clear that the right to development, including through resource extraction, should be a "reality for everyone" and that globalization should be "a positive force for all the world's people."161

Borne out of the Millennium Declaration were the Millennium Development Goals (MDGs), a set of eight goals ${ }^{162}$ aimed at addressing the ideals set forth in the Millennium Declaration. ${ }^{163}$ The adoption of the MDGs further underscores that States accept the responsibilities and obligations set out in the Declaration on the Right to Development. ${ }^{164}$ In addition, the fact that the MDGs are specifically intended to benefit the people is reflected by the commitments made to "reduce poverty and hunger, to tackle ill health, gender inequality, lack of education, lack of access to clean water, and environmental degradation." 165

In order to reach the MDGs and achieve the benefits sought, several international initiatives are centered on achieving these goals. Then Secretary General of the U.N., Kofi Annan, sanctioned the U.N. Millennium Project to help recommend a plan for achieving the MDGs by $2015{ }^{166}$ The Project was an independent advisory composed of experts in development and sustainability that was tasked with identifying practical steps to achieve

\footnotetext{
160 John W. McArthur, Own the Goals: What the Millennium Development Goals Have Accomplished, FOREIGN AFFAIRS, Mar./Apr. 2013, available at http://www.foreignaffairs. com/articles/138821/john-w-mcarthur/ownthe-goals (noting that the "heads of state accepted that they needed to work together to assist the world's poorest people").

${ }^{161}$ United Nations Millennium Declaration, G.A. Res. 55/2, ๆ 5, 11, U.N. Doc. A/RES/55/2 (Sept. 18, 2000).

162 Goals, Targets and Indicators, U.N. MiLLENNIUM PROJECT, http://www.unmillenniumproject. org/goals/gti.htm\#goall (last visited Aug. 5, 2014) (the eight goals are as follows: (1) eradicate extreme poverty and hunger; (2) achieve universal primary education; (3) promote gender equality and empower women; (4) reduce child mortality; (5) improve maternal health; (6) combat HIV/AIDS, malaria, and other diseases; (7) ensure environmental sustainability; and (8) forge global partnerships among different countries and actors to achieve development goals).

163 Jeffrey D. Sachs, Investing in Development: A Practical Plan to Achieve the Millennium Development Goals, U.N. MiLlENNIUM PROJECT 1 (2005), available at http://www.unmillenn iumproject.org/documents/overviewEngLowRes.pdf (stating that MDGs are the world's timebound and quantified targets for addressing extreme poverty and basic human rights issues, as well as promoting gender equality, education, and environmental sustainability).

164 Gathii, supra note 159 , at 261.

165 Andy Haines \& Andrew Cassels, Can the Millennium Development Goals be Attained?, BMJ, Aug. 12, 2004, at 394, available at http://www.bmj.com/content/329/7462/394.

${ }^{166} Q \& A$ on the Millennium Project and its Report, U.N. MillenNiUm ProJeCt, http://www. unmillenniumproject.org/resources/qa.htm (last visited July 31, 2014).
} 
the MDGs in every country. ${ }^{167}$ The core recommendation of the Project is that the MDGs should be at the forefront of national and international poverty reduction strategies. ${ }^{168}$ Further, that developing countries must assess where they stand on achieving the MDGs and take the necessary interventions to meet the 2015 deadline.

Other entities that have played an important role in helping to achieve the MDGs and further development around the world include civil society organizations like ActionAid or the International Planned Parenthood Federation. ${ }^{169}$ These organizations can raise awareness about the MDGs, mobilize support among key constituencies to keep pressure on leaders to follow through on commitments related to the MDGs, and can monitor progress and maintain transparency in investment, extraction or other development programs. ${ }^{170}$

Another such initiative is the Millennium Cities Initiative (MCI), which was set up in association with the Millennium Project. ${ }^{171}$ MCI's focus is on helping certain sub-Saharan African cities achieve the MGDs. ${ }^{172}$ MCI's prepared report on resource-rich Blantyre, Malawi, found that investment in mining between 1999 and 2007 accounted for $73 \%$ of all foreign direct investment, and that further investment in mining presents a growing opportunity for development. ${ }^{173}$ A similar report on development in the lower Zambezi basin found that Mozambique could utilize its vast resources to achieve a major boost to its economic development. ${ }^{174}$

\footnotetext{
167 Jeffrey D. Sachs, The Millennium Project: A Plan for Meeting the Millennium Development Goals, 365 LANCET 347 (2005), available at http://www.thelancet.com/journ als/lancet/article/PIIS0140-6736(05)17791-5/fulltext.

168 About the U.N. Millennium Project, U.N. MillenNiUm Project, http://www.unmillenni umproject.org/who/index.htm (last visited Aug. 5, 2014) (discussing the project and its goals); see also Sachs, supra note 163 (giving a more detailed analysis of the Project's ten recommendations).

169 Sachs, supra note 163, at 18 (other civil society organizations include Bread for the World, CIVICUS, DATA, Development Alternatives with Women for a New Era (DAWN), Médecins sans Frontières, InterAction, Oxfam, RESULTS International, and Social Watch).

${ }^{170}$ Id.

${ }^{171}$ Malawi Blantyre, Potential Opportunities for Investment, KPMG 3 (Oct. 2009), available at $\mathrm{http}: / /$ academiccommons.columbia.ed/cataglo/ac\%3 A135570.

${ }^{172}$ Id.

173 Id. at $13,43$.

174 See Zambazi Valley Development Study, Columbia CTr. On Sustainable Inv. (June 6, 2011), http://ccsi.columbia.edu/2011/06/26/zambezi-valley-development-study/; see also Lisa Sachs et al., Resource-Based Sustainable Development in the Lower Zambezi Basin, VALE Columbia Ctr. on Sustainable InT'L Inv. (June 1, 2001).
} 
While these are just some examples of international developments and strategies, it is clear that the right to development, including through resource extraction, is not only a right that belongs to the people, but is also a right that should primarily benefit them.

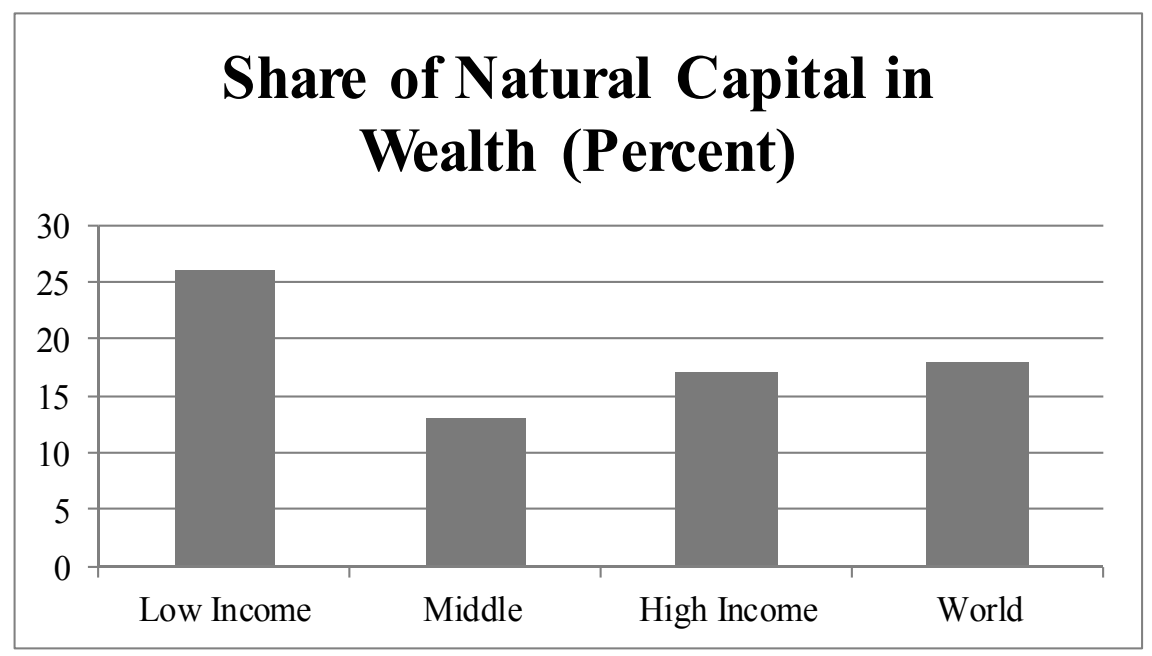

Figure 1

Governments and investors argue that the development of natural resources is, not only for the benefit of investors, but also for the greatest possible benefit of the people in the country where the resources are located. Resource contracts therefore embody a very important underlying understanding - that they are an essential link to a country's development. Botswana is an excellent example on how best to use natural resources to facilitate economic growth and development. The following illustration demonstrates how Botswana has contributed to its national wealth and economic growth from the mining of its natural resources such as diamonds. 
Growth of real per capita wealth and real per capita GDP in Botswana

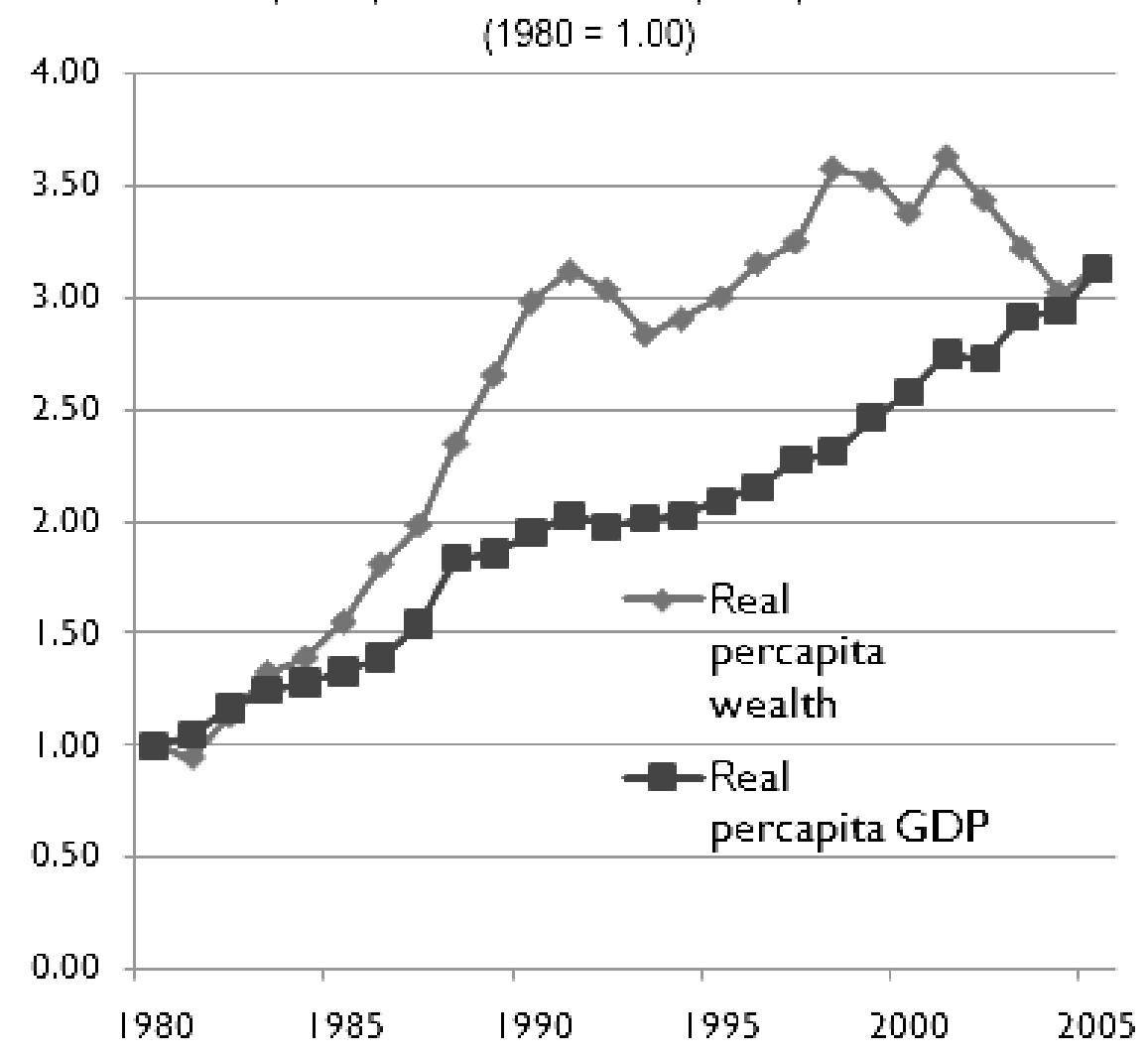

Figure $2^{175}$

\footnotetext{
175 The Changing Wealth of Nations: Measuring Sustainable Development for the New Millennium Released, WorLD BANK (Jan. 24, 2011, 9:13 AM), http://data.worldbank.org/ news/the-changing-wealth-of-nations.
} 


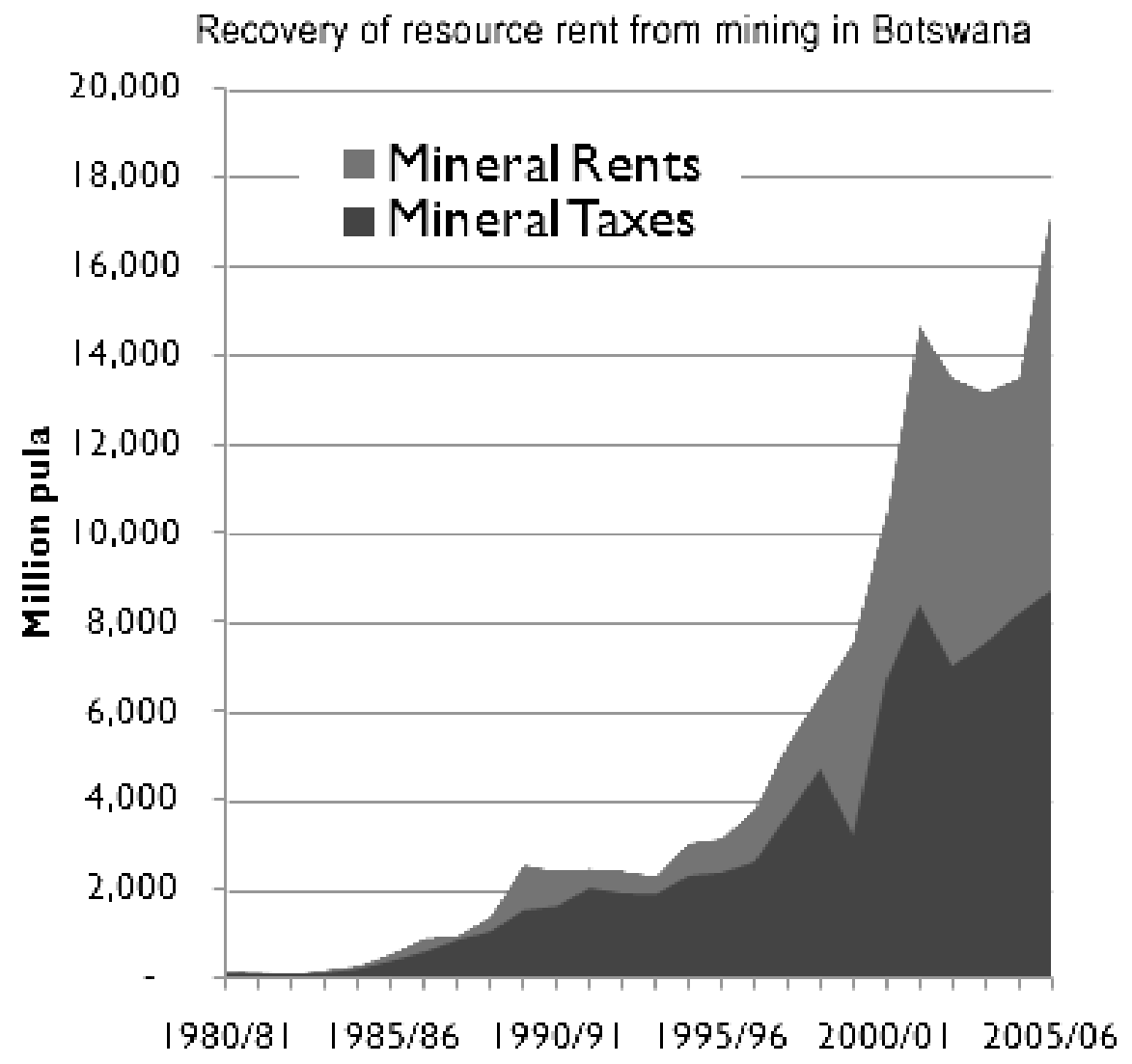

Figure $3^{176}$

And, as the figure above demonstrates, there is potential for resource-rich countries to grow their economies from mineral rents and taxes.

Today, the international legal principle of Permanent Sovereignty Over Natural Resources is understood not merely as conferring on States the right to control the use of natural resources within its territory, but also as obliging states to proactively use those resources for the benefit of their people. ${ }^{177}$ To

\footnotetext{
${ }^{176}$ Id. In February 2013, one Botswana Pula is of equal value to twelve U.S. Cents - that means sixteen trillion Pula is of equal value to one billion U.S. Dollars.

177 Kamal Hossain, Introduction to Kamal Hossain \& Subrata Roy Chowdhury, Permanent Sovereignty Over Natural Resources in International LaW, at ix-xx (Kamal Hossain \& Subrata Roy Chowdhury eds., 1984); Emeka Duruigbo, Permanent
} 
illustrate, the Declaration provides in part that "The right of peoples and nations to permanent sovereignty over their natural wealth and resources must be exercised in the interest of their national development and the wellbeing of the People of the State concerned."178 This Declaration does not create a right to assist citizens - it creates a duty.

Further, the Inter-American Court of Human Rights has recognized the rights of indigenous and non-indigenous groups to the natural resources within their lands. ${ }^{179}$ In the 2001 case between Awas Tingni Community and the government of Nicaragua, the Inter-American Court of Human Rights recognized indigenous peoples' right to their land and affirmed that all people - including indigenous people - have the right to the "use and enjoyment of his property" pursuant to the American Convention on Human Rights. ${ }^{180}$ For its part, the African Commission on Human and Peoples' Rights has construed Article 21 of the African Charter on Human and Peoples' Rights, which gives people the right to dispose of their natural resources as obliging African governments to protect their citizens from damaging conduct perpetrated by private actors. In this case, SERAC v. Nigeria, the Ogoni community of the Niger Delta alleged that the Nigerian government through its state owned oil company, which was in a consortium with Shell Petroleum Development Corporation, had exploited oil reserves in a manner that had degraded the environment, caused short-term and longterm adverse impacts on the people and repressed the protests of the Ogoni people with violence and execution of their leaders. ${ }^{181}$ The Commission found the Nigerian government liable for violating Article 21 (disposition of natural resources shall be exercised for the exclusive interest of the people); Article 24 (the right to a general satisfactory environment favorable to the development of peoples); Article 14 (right to property); Article 18 (failure of

Sovereignty and Peoples' Ownership of Natural Resources in International Law, 38 GeO. WASH. INT'L L. REV. 33, 66-67 (2006).

178 Permanent Sovereignty Over Natural Resources, G.A. res. 1803 (XVII), U.N. Doc. A/5217 (Dec. 1962); see also Theodore Macdonald, Inter-American Court of Human Rights Rules in Favor of Nicaraguan Indians, 25.4 Cultural SuRvival Q., Winter 2001, available at http://www.culturalsurvival.org/publications/cultural-survival-quarterly/nicaragua/inter-am erican-court-human-rights-rules-favor-nic.

179 See Lisl Brunner, The Rise of Peoples' Rights in the Americas: The Saramaka People Decision of the Inter-American Court of Human Rights, 7 CHINESE J. INT'L L. 699, 699 (2008).

${ }^{180}$ The Mayagna (Sumo) Awas Tingni Community v. Nicaragua, Merits, Reparations and Costs, Inter-Am. Ct. H.R. (Ser. C) No. 79, 145 (Aug. 31, 2001).

${ }^{181}$ The Social and Econ. Rights Action Ctr. and the Ctr. for Econ. and Soc. Rights v. Nigeria, African Comm'n on Human and Peoples' Rights (Comm. No. 155/96 of 2001), http:// www1.umn.edu/humanrts/Africa/comcases/155-96.html. 
the state to protect the family as the natural unit and basis of society); Article 4 (right to food); and Article 16 (right to health). ${ }^{182}$

\section{Interests of Justice and Morality}

Although natural resources are a major source of the wealth of many lowincome resource-rich countries, such wealth is also highly correlated with the initiation, duration and persistence of violence. ${ }^{183}$ This violence has resulted in huge losses of human lives, property and the quality of lives of those that survive the violence. Resource rich countries like the Democratic Republic of Congo and Angola have a weak rule of law system, weak governance institutions that are bedeviled with corruption. These institutions divert the wealth from natural resources from the national treasury for private gain.

The mineral wealth of low-income resource rich countries can be used to finance capital enhancing programs such as infrastructure as well as important social programs in education, water, food and health as well as to fund social protection programs for the most vulnerable citizens and to save some of the income to ensure availability of financing when there is a downswing in commodity prices.

In the foregoing sense, the Third Party Beneficiary Principle in resource extraction contracts is consistent with the interests of justice and morality. The underlying assumption here is that it is the just and moral thing for lowincome, resource dependent countries to invest income from their mineral wealth for the benefit of their current and future generations. Under this

\footnotetext{
182 Two new cases from the Supreme Court of Canada have articulated a new duty on the Crown - the constitutional duty to implement the honor of the Crown. The new duty described by the Supreme Court of Canada in these two cases is described as a duty to consult and accommodate. The Court stated that the duty is grounded in the honor of the Crown and emphasized that this principle is always at stake in its dealings with Aboriginal peoples. The Court held that:

$[T]$ he historical roots of the principle of the honor of the Crown suggest that it must be understood generously in order to reflect the underlying realities from which it stems. In all its dealings with Aboriginal peoples, from the assertion of sovereignty to the resolution of claims and the implementation of treaties, the Crown must act honorably. Nothing less is required if we are to achieve "the reconciliation of the pre-existence of Aboriginal societies with the Sovereignty of the Crown."

Jean Teillet, The Role of the Natural Resources Regulatory Regime in Aboriginal Rights Disputes IN ONTARIO 60 (Mar. 31, 2005) (citing Haida Nation v. British Columbia (Ministers of Forests), 2004 S.C.C. 73, 917 ).

${ }^{183}$ Paul Collier, The Bottom Billion: Why the Poorest Countries Are Failing and What Can Be Done About It (2007).
} 
justification, the Third Party Beneficiary Principle arises independently of the express wishes of the parties to a resource extraction contract. ${ }^{184}$

Such an approach to the Third Party Beneficiary Principle is contemplated by Restatement Second of Contracts Section 204, comment d, which provides that: "[W]here there is in fact no agreement [on a matter that falls within the ambit of a contract], the courts should supply a term that comports with community standards of fairness and policy rather than analyze a hypothetical model of the bargaining process."

Such theories of fairness, justice and morality have increasingly become part of the discussion on international economic law in general and international trade law in particular. ${ }^{185}$ In the extractive industries context, issues of justice and morality are particularly relevant. This is because these natural resources not only offer the best hope for addressing the pressing social and other challenges citizens of poor countries face, but also because the extraction of resources such as oil, hard-wood timber and minerals like diamonds is highly correlated with violence and massive abuses of human rights. Unfortunately, the majority of citizens in resource-rich countries are at the very bottom of the global income ladder as the illustration below demonstrates. ${ }^{186}$

\footnotetext{
184 Eisenberg, supra note 41, at 1387.

185 Frank J. Garcia, Global Justice and International Economic Law: Three Takes (2013).

186 In countries like Canada, the rights of indigenous people must be specifically consulted. See supra note 182. That is not the case in other contexts. See, e.g., for example, Joel Ngugi, The Decolonization-Modernization Interface and the Plight of Indigenous Peoples in PostColonial Development Discourse in Africa, 20 WIS. INT'L L.J. 297, 350 (2002) (discussing how the process of transposing the decolonization movement into an elaborate modernization program aimed at achieving "economic development" enabled a parallel process of silencing, dominating, and disempowering other sectors within the African State. In the silencing, constraining and shaping that takes place, the Third World State is required, yet prevented from acquiring full status as a modernized state, while the indigenous groups within the Third World state are required, yet prevented from becoming fully modernized.).
} 


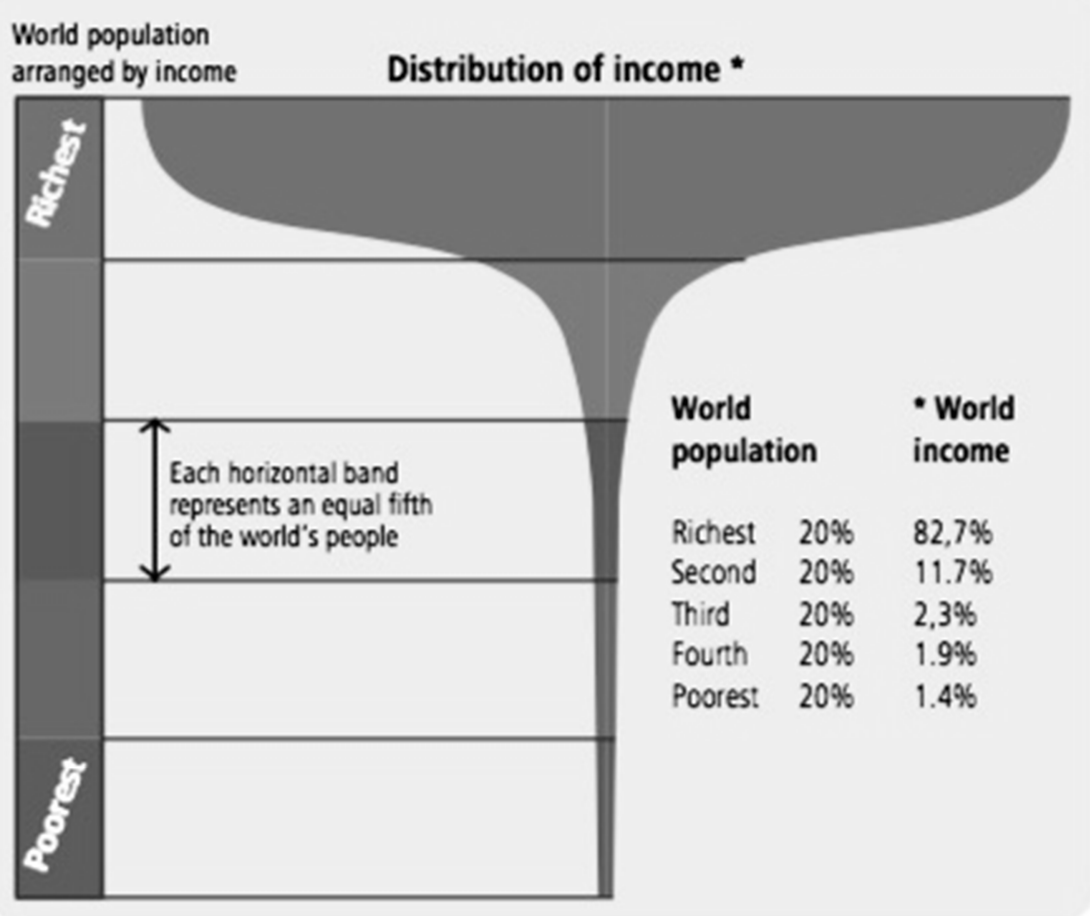

Figure $4^{187}$

Take the example of commercial timber logging - in countries as diverse as Brazil and Cameroon, loggers undermine the rights of forest peoples to manage and control the lands they call home and on which they rely not only for their livelihood, but also rely on for cultural and religious purposes. Loggers interfere with fishing, collecting, and hunting practices of forest communities thereby threatening their subsistence and cultural survival. ${ }^{188}$ In short, mining, petroleum, logging, agribusiness, ranching, and tourism activities under-mine the ability of local communities to depend on the only resources they depend for their livelihoods and their cultural identity.

187 U.N. Environment Programme, Green Economy: Poverty Reduction 1 (2012), available at http://www.unep.ch/etb/publications/GE\%20Briefs\%202012/Briefing\%20paper \%20GE_POVERTY\%20REDUCTION.pdf.

${ }^{188}$ Logging Impacts, SIERRA FOREST LEGACY (2012), available at http://www.sierraforestle gacy.org/FC_FireForestEcology/FFE_LoggingImpacts.php. 
That is why it is important to structure resource extraction contracts in a way that explicitly accommodates the interests of these communities. Recognizing third party beneficiary rights is a superior way of accommodating the rights of affected communities than approaches that try to hold governments and resource extraction companies liable after the fact. Promoting accountability is vastly important, especially in low-income, resource-rich communities where powerful private parties could otherwise exercise their wealth, power, and access to corrupt governmental officials to the detriment of the citizens - to illustrate, the extraction of minerals accounts for only about $1 \%$ of African countries' gross domestic product, though it accounts for $70 \%$ of their total exports. ${ }^{189}$

Further, to promote the interests of justice and morality, in order to avoid exploitation of the natural resources of developing countries is through transparency initiatives. One initiative at the forefront of the push towards better "global governance" is the Kimberley Process Certification Scheme (KPCS). ${ }^{190}$ The KPCS is an "international certification scheme aimed at preventing the world diamond trade from funding conflicts and fueling human rights abuses."191 The KPCS requires member countries to enact legislation that regulates, monitors, and ensures "conflict-free" diamond trading. ${ }^{192}$ Considering the adverse consequences to people that previously stemmed from the diamond trade, a key feature of the KPCS is the threat of expulsion from the KPCS that participating countries face for noncompliance, which can lead to a ban on trading with other KPCS members. ${ }^{193}$ By extension, protecting people from violence and other human rights violations is so important that the KPCS's restriction on diamond trade

\footnotetext{
189 James Thuo Gathii, Beyond China's Human Rights Exceptionalism in Africa: Leveraging Science, Technology and Engineering for Long-Term Growth, 51 ColuM. J. TRANSNAT'L L. 664, 678 (2013) (citing Avantika Chilkoti, Africa's Extractive Industries: Dividing the Spoils, Fin. Times (Oct. 17, 2012, 8:51 AM), http://blogs.ft.com/beyond-brics/2012/10/17/africas-ext ractive-industry-dividing-the-spoils).

190 Andrés Meijía Acosta, Impact and Effectiveness of Transparency and Accountability Initiatives: Natural Resource Governance, INST. DEV. STUD. (Oct. 1, 2010), available at http:// www.ids.ac.uk/files/dmfile/IETAAnnex4NatResGovMejiaAcostaFinal28Oct2010.pdf.

${ }^{191}$ An Independent Commissioned Review Evaluating the Effectiveness of the Kimberley Process, GlOBAL WiTnESs 1 (2006) available at http://www.globalwitness.org/sites/default/ files/import/GW\%20Commissioned\%20Report\%20on\%20KP.pdf [hereinafter Effectiveness of the Kimberley Process].

192 See generally KimBERley Process, supra note 29 (describing the composition, structure, and function of the Kimberley Process).

193 Effectiveness of the Kimberley Process, supra note 191, at 5.
} 
is allowed to operate by virtue of a rare waiver to the free trade rules of the World Trade Organization policy that promotes free trade. ${ }^{194}$

Perhaps the most well known global transparency initiative is the Extractive Industries Transparency Initiative (EITI). ${ }^{195}$ The EITI has evolved into the model disclosure standard implemented by countries to resource extraction agreements. ${ }^{196}$ The purpose behind the EITI is to allow citizens to track government spending and revenues from the country's natural resources, as well as promote greater accountability for such accounting practices. ${ }^{197}$

An example of legal action at the domestic level is the United States' adoption of an amendment to Section 1504 of the Dodd-Frank Wall Street Reform and Consumer Protection Act that would require disclosure of payments by resource extraction issuers. ${ }^{198}$ The disclosure requirements in the Act are specifically intended to complement international transparency efforts like the EITI. ${ }^{199}$ The purpose behind the required disclosures is to increase the transparency of payments made by resource extraction companies to governments related to commercial development. ${ }^{200}$ The central goal of increased transparency under the Act "is to help empower citizens of those resource-rich countries to hold their governments accountable for the wealth generated by those resources."201

Furthermore, these transparency initiatives are indicative of the fact that resource extraction and development should primarily benefit the people. ${ }^{202}$

\section{Public Policy Rationales}

As we saw above, rules of international law and national Constitutions recognize and declare the interests peoples have natural resources found in

\footnotetext{
194 See Agreement Reached on WTO Waiver for "Conflict Diamonds," WTO News (Feb. 26, 2003), http://www.wto.org/english/news_e/news03_e/goods_council_26fev03_e.htm; see also Isabel Feichtner, The Waiver Power of the WTO: Opening the WTO for Political Debate on the Reconciliation of Competing Interests, 20 EUR. J. INT'L L. 3 (2009).

195 What is the EITI?, EXTRACTIVE InDUS. TRANSPARENCY InITIATIVE, http://www.eiti.org/ eiti (last visited Aug. 5, 2014).

${ }^{196}$ Id.

${ }^{197} I d$.

198 Dodd-Frank Wall Street Reform and Consumer Protection Act, Pub. L. No. 111-203, $\S 1504,124$ Stat. 1376 (July 21, 2010).

199 Disclosure of Payments by Resource Extraction Users, File No. S7-42-10, at 9 (Nov. 13, 2012) (to be codified at 17 C.F.R. $\S \S 240,249$ ).

200 Id. at 5.

${ }^{201}$ Id. at 5-6.

202 See supra Part III.A.
} 
their countries and localities. To illustrate how this public interest recognition in natural resources is reflected in practice, this section discusses how this principle has received judicial recognition. The example I use invoked the Indonesian Constitution, which in the relevant part provides that "The land, the waters and the natural resources within shall be under the powers of the State and shall be used to the greatest benefit of the people."203

This principle of public ownership of natural resources in Indonesia was consequential in a United States Federal Circuit case, Karaha Bodas Co. v. Perushaan Petrambangan Minyak Dan Gas Bumi Negara. ${ }^{204}$ The issue in this case was whether trust funds held in fifteen Bank of America accounts from the sale of liquefied natural gas in Indonesia could be attached to satisfy an unrelated arbitration award of \$261 million that KBC won against the government of Indonesia. ${ }^{205}$ The funds were held by an Indonesian governmental entity, Pertamina, whose goal under Indonesian law was to "to develop and carry out the exploitation of oil and natural gas ... for the maximum prosperity of the People and the State."206

There are two ways in which Karaha Bodas is important to illustrate how public policy is critical in resolving legal challenges relating to extractive industry disputes. First, although $\mathrm{KBC}$ - the corporation in the case-only sued Pertamina, the Indonesian agency charged with the development of liquefied natural gas, the Second Circuit allowed Indonesia's Ministry of Finance to participate in the appeal although it had been a non-party in the proceedings before the District Court. ${ }^{207}$ The Ministry became involved only after KBC attached the trust accounts at Bank of America. ${ }^{208}$ The Second Circuit justified its decision based on precedent, noting that

In Devlin v. Scardelletti, 536 U.S. 1, 122 S. Ct. 2005, 2008, 2013 (2002), the Court held that an unnamed member of a class could appeal a class action settlement at a fairness hearing even though he had failed to intervene earlier. The Court cautioned that '[t]he label 'party' does not indicate an absolute

\footnotetext{
203 ThE 1945 CONST. OF THE REPUBLIC OF INDON., art. 33, § 3, available at http://www.ilo.org/ wcmsp5/groups/public/---ed_protect/---protrav/---ilo_aids/documents/legaldocument/wcms_174 556.pdf.

204313 F.3d 70 (2d Cir. 2002).

205 Id. at $75,77-78$.

206 Id. at 75.

207 Id. at 81.

208 Id.
} 
characteristic, but rather a conclusion about the applicability of various procedural rules that may differ based on context."209

Therefore, to the extent to which a non-party's interest may be affected by enforcing a judgment to which he or she did not participate, that non-party would allowed to participate in proceedings related to execution or attachment of the judgment.

Second, and equally important, the Second Circuit applied Indonesian law to determine the ownership of the funds in the trust accounts. ${ }^{210}$ New York's choice of law rules dictate that the rules to determine ownership are those of the jurisdiction with the "greater interest," and the facts and contacts that are significant in determining the interests of the state are those that relate to the purpose of the law in question. ${ }^{211}$ Under this test, the Second Circuit determined that the overwhelming weight of interests in the trust accounts favored the application of Indonesian rather than New York law in determining ownership of the Trust funds. ${ }^{212}$

The Second Circuit concluded that New York's interests were attenuated. $^{213}$ According to the Court, an examination of Indonesian law under which Pertamina was established evinced a "significant national interest" in the fate of the trust funds. ${ }^{214}$ Determining whether or not New York or Indonesian law was applicable was therefore critical. KBC argued in vain that because Pertamina controlled the trust accounts, it owned all the funds in the account, and as such they were all attachable to satisfy the arbitral award. ${ }^{215}$ The Second Circuit was not convinced-it agreed with the Indonesian Ministry and applied Indonesian law, holding that only 5\% of the trust accounts that Pertamina owned were attachable. ${ }^{216}$

\footnotetext{
209 Id.

$210 \mathrm{Id}$. at 87.

${ }^{211} I d$. (the Indonesian interest in the funds was the maintenance of satisfactory exchange rate reserves. Such reserves are critical for countries to be able to effectively participate in international trade.).

${ }^{212} I d$.

213 Id. (according to the Second Circuit "New York statutory interests implicated here are relatively attenuated: (i) the creation and operation of trusts under New York law; (ii) the execution of sales contracts that operate under New York law to obtain funds for deposit in these trusts; (iii) New York's general interest 'in defining and protecting the property interests of its citizens and those who do business there,'....; and (iv) New York's 'interest as an international clearinghouse and market place ....',").

${ }^{214} I d$.

215 Id. at 83, 88.

${ }^{216}$ Id. at 92.
} 
The Second Circuit found that the rest of the Trust funds were held in a constructive trust for the government of Indonesia. ${ }^{217}$ Because funds held in trust by Pertamina belonged to another party, the Second Circuit concluded that they were not subject to attachment under the law. ${ }^{218}$

Ultimately, this Article uses Karaha Bodas to make two points. First, that it is important to observe how public interest analysis is embedded in transactional disputes relating to resource extraction. Here a conflict of law analysis allows the Indonesian ministry to appear as a non-party on appeal in the case since it is able to show interest in the money in issue. ${ }^{219}$ This interest was so significant that the Second Circuit held that its participation on appeal was permissible even if it had not been a party to the case in the district court. ${ }^{220}$ Second, the Second Circuit upheld the view embodied in Indonesian law, that the revenue generated from extracting liquefied natural gas was held in a constructive trust on behalf of the government and effectively of the people of Indonesia. ${ }^{221}$ In these two respects, the Second Circuit upheld the interests of the government of Indonesia against those of a foreign investor. The Court declined to expand the remedies for $\mathrm{KBC}$ beyond those for which $\mathrm{KBC}$ had negotiated. ${ }^{222}$

Further, unlike under colonial times, when resources were appropriated through capitulation treaties, contracts today govern access to these resources in a manner that balances the rights of investors and governments. ${ }^{223}$ Karaha Bodas demonstrates the importance and potential of pursuing transactional, and, in my view, contractual-approaches, to ensuring that beneficiaries of these resources actually benefit.

\footnotetext{
${ }^{217} I d$.

${ }^{218} I d$. at $92-93$.

219 Id. at 81 .

${ }^{220}$ Id.

221 Id. at 88.

${ }^{222}$ Karaha Bodas Company LLC (KBC) is a company incorporated in the Cayman Island and owned by American power companies. Karaha Bodas Co. v. Perusahaan Pertambangan Minyak Dan Gas Bumi Negara, 500 F.3d 111, 113 (2d Cir. 2007).

${ }^{223}$ James Thuo GHatti, WAR, COMMERCE AND InTERNATIONAL LAW 153-54 (2011) (arguing that international lawyers of the early twentieth century came to believe that investorstate arbitration was "an example of a larger set of voluntary and consensual processes that States could use to resolve conflicts rather than resorting to war. These lawyers celebrated international law as a non-coercive solution through which problems, domestic and international, could be cooperatively and beneficially resolved.").
} 


\section{OBJECTIONS AND RESPONSES TO THIRD PARTY BENEFICIARY STANDING IN RESOURCE CONTRACTS}

Parties often enter into contracts to enhance their wealth through exchange and to make reliable plans. ${ }^{224}$ Moving from this premise, objections against the Third Party Beneficiary Principle are advanced because the Principle interferes with the ability of contracting parties to enhance their wealth and make reliable business plans. ${ }^{225}$ A similar objection is that the Third Party Beneficiary Principle upsets the stability of the contractual relations between promisor and promisee. ${ }^{226}$ Indeed, this stability lies at the heart of contract law. ${ }^{227}$ According to this view, "[c]ontract liability, unlike tort liability, is based almost entirely on a consensual relationship," 228 and that its policy underpinnings are "more concerned with enforcing privately made bargains than with coercing behavior." 229

The response to these objections is that third party beneficiary status is consistent with exchanged promises in resource extraction contracts. ${ }^{230}$ In other words, allowing third parties to sue is necessary to effectuate the intentions of the parties to the contract. ${ }^{231}$ Thus the ability to sue on the part of a third party here is remedial, not substantive. ${ }^{232}$ It is remedial because the third party seeks to enforce the contracting parties' promises. Here, third party standing would not necessarily depend on proving that the contracting parties actually intended to benefit the third party, but instead depends on effectuating the will of the parties.

In addition, the objective of benefiting the local population lies at the core of resource extraction contracts. A government contracting with an investor does not do so on its own behalf, but rather on behalf of its citizens. This relationship is perhaps most apparent in contracts for public services. Yet, in

\footnotetext{
${ }^{224}$ Eisenberg, supra note 41, at 1374.

${ }^{225} \mathrm{Id}$. at 1376.

226 Id. at 1386.

227 Id. at 1374 .

228 Jean Fleming Powers, Expanded Liability and the Intent Requirement in Third Party Beneficiary Contracts, 1993 UTAH L. REV. 67, 79.

${ }^{229}$ Id. at 80.

${ }^{230}$ Eisenberg, supra note 41, at 1386.

231 Id.

${ }^{232} I d$.
} 
the end, all government contracts are contracts for public services, because the fundamental nature of government is to serve its citizens. ${ }^{233}$

The paradigm of governments contracting with investors for the benefit of their citizens finds support in the theory of public trust. ${ }^{234}$ Under this theory, the nation-state claims ownership over the natural resources collectively belonging to the "people."235 Its government, therefore, holds and administers the property in trust and, as the "people's" representative, owes the people duties of loyalty, care, and good faith. ${ }^{236}$ Where the government holds natural resources in such public trust, "there exists in every contractual agreement between MNCs [multinational corporations] and host governments a silent and innumerable group of parties in interest: the 'people' as third-party beneficiaries of all such investment contracts." 237

In further response to the stated objections, contracting parties can employ drafting techniques to minimize the extent to which third party rights interfere with the parties' ability to enhance wealth and make reliable business plans. For example, in resource extraction contracts with third world governments, MNCs manage risk by including provisions that waive sovereign immunity and compel arbitration. Together, such provisions could permit MNCs to seek contribution from contracting governments when facing lawsuits by community members. ${ }^{238}$ Business plans would, therefore, be reliable because the financial burden of resolving litigation would ultimately fall on the parties in proportion to their culpability under the contracts, if any.

Another objection to adoption of the Third Party Beneficiary Principle is that it would open the floodgates of litigation against private parties

\footnotetext{
233 See Patience A. Crowder, More than Merely Incidental: Third-Party Beneficiary Rights in Urban Redevelopment Contracts, 17 Geo. J. ON Poverty L. \& POL'y 287, 318 (2010) (discussing third party beneficiaries of urban redevelopment contracts).

${ }^{234}$ See supra note 136 (discussing the evolution of the public trust doctrine).

235 See Wendy N. Duong, Partnerships with Monarchs-Two Case Studies: Case Two: Partnerships with Monarchs in the Development of Energy Resources: Dissecting an Independent Power Project and Re-Evaluating the Role of Multilateral and Project Financing in the International Energy Sector, 26 U. PA. J. INT'L ECON. L. 69, 134 (2005) (proposing that the legal concepts of public trust, corporate derivative fiduciary duty, and third party beneficiary should govern certain types of business partnerships between third world governments and MNCs).

236 Id.

237 Id. at 136

238 See Roger P. Alford, Arbitrating Human Rights, 83 Notre Dame L. Rev. 505, 517-28 (2008) (discussing how contract and arbitration law could provide recourse for corporations held liable for international human rights violations when the contracting sovereign is jointly or exclusively responsible).
} 
contracting with the government. This is because government contracts benefit a large number of people and, as such, allowing third parties to sue on those contracts would subject investors and governments to endless litigation. Justice Cardozo objected to precisely such a possibility in H.R. Moch Co. v. Rensselaer Water Co. ${ }^{239}$ The dissent in Just's, Inc. v. Arrington Construction Co. raised similar objections. ${ }^{240}$

Another objection to the Third Party Beneficiary Principle is that, if adopted, it could potentially impose liability greatly disproportionate to the potential benefits that investors stand to receive under government contracts. $^{241}$ However, it is notable that the largest flows of foreign direct investment in Africa are highest in resource-rich countries such as Angola notwithstanding the political instability in those countries. ${ }^{24}$ In short, despite political instability, there are great gains to be made from extractive resources. Unsurprisingly, investors and financiers in the natural resource extraction industry argue that they make natural resource investments not only for their benefit, but also to benefit local populations.

Another objection is that investors will not assent to third party beneficiary clauses when contracting with governments. The objection is similar to the argument doubting investors' willingness to accept contracts that adopt the Organization for Economic Co-operation and Development's (OECD) Guidelines for Multinational Enterprises. ${ }^{243}$ These Guidelines promote responsible business conduct worldwide by making MNCs

239 According to Justice Cardozo,

A member of the public may not maintain an action under Lawrence v. Fox against one contracting with the city to furnish water at the hydrants, unless an intention appears that the promisor is to be answerable to individual members of the public as well as to the city for any loss ensuing from the failure to fulfill the promise.

H.R. Moch Co. v. Rensselaer Water Co., 159 N.E. 896, 897 (1928),

240 Just's Inc. v. Arrington Constr. Co., 583 P.2d 997, 1006-08 (Idaho 1978) (Donaldson, J., dissenting) (warning that, by allowing a member of the public to sue for breach of a public works contract between the government and a contractor, the majority was "open[ing] the door for numerous third party beneficiary suits involving governmental contracts").

${ }^{241}$ Eisenberg, supra note 41, at 1407.

${ }^{242}$ United Nations Conference on Trade and Development, New York and Geneva, 2001, World Investment Report-Overview-Promoting Linkages, UNCTAD/WIR/2001 (Sept. 17, 2001); see also United Nations Conference on Trade and Development, New York and Geneva, 2006, World Investment Report: FDI From Developing and Transition EconomiesImplications for Development (Oct. 15, 2006) (showing that this trend has continued because of the boom in natural resources in recent times).

${ }^{243}$ See Evaristus Oshionebo, The OECD Guidelines for Multinational Enterprises as Mechanisms for Sustainable Development of Natural Resources: Real Solutions or Window Dressing?, 17 LEWIS \& CLARK L. REV. 545, 589 (2013). 
responsible to "respect and uphold human rights, workers' rights, and environmental sustainability within the framework of international instruments." 244 However desirable it may be for developing countries to incorporate the OECD Guidelines into contracts, the intense competition among recipients for foreign investment coupled with the financial power and influence of MNCs, render the incorporation of these guidelines unlikely at the moment. ${ }^{245}$

Yet, objections to inclusion of contractual terms unfavorable to investors are overstated. This is well illustrated by countries' that have succeeded in adding provisions to contracts against private investors' initial objections. To illustrate, Botswana negotiated extremely generous royalty payments that a very powerful investor, De Beers, strongly protested. ${ }^{246}$ After lengthy negotiations where Botswana contended that the initial contract with De Beers was unfair, Botswana prevailed. ${ }^{247}$

Additionally, some MNCs take affirmative steps to prevent human rights violations. $^{248}$ For example, a study of fourteen Dutch MNCs found that almost all of them required supply partners to sign codes of conduct, many of which became binding through incorporation into supply contracts. ${ }^{249}$ These codes of conduct included codes of social responsibility, extending to treatment of the suppliers' and sub-suppliers' employees, which in many cases established legally enforceable third-party beneficiaries. ${ }^{250}$

The Dutch are not the only investors willing to bind themselves to protect third world citizens. Some contracts between resource extraction companies and developing countries incorporate the World Bank's social standards. ${ }^{251}$ For example, the Chad-Cameroon Petroleum Development and Pipeline

\footnotetext{
${ }^{244} I d$.

${ }^{245} I d$.

246 Stiglitz Warns Against IMF “Inflation targeting," ZIMBABWEAN (July 12, 2013, 7:53 AM), http://www.thezimbabwean.co/news/africa/59434/stiglitz-warns-against-imf-inflation.html. Stiglitz notes that renegotiation has always been part of capitalism. Botswana's success began with renegotiating the unfair contract that De Beers, the South African diamond company, had secured prior to Botswana's independence. Originally, De Beers protested, but it eventually agreed that a fairer contract was in both parties' best interests. Similarly, Australia, Bolivia and Venezuela are among the other countries that have successfully renegotiated contracts. See JOSEPH E. STIGLITZ, GLOBALIZATIONS AND ITS DiSCONTENTS 39 (2002).

247 Stiglitz Warns Against IMF “Inflation targeting," supra note 246.

${ }^{248}$ Louise Vytopil, Contractual Control and Labour-Related CSR Norms in the Supply Chain: Dutch Best Practices, 8 Utrecht L. ReV. 155, 156 (2012).

${ }^{249}$ Id. at $166-67$.

${ }^{250}$ Id. at $161-62,168$.

251 Oshionebo, supra note 243, at 588.
} 
Project incorporates the World Bank's environmental standards. ${ }^{252}$ These examples demonstrate that the objection that investors would prohibit third party beneficiary clauses is overstated, and that even if investors did object to third party beneficiary clauses, their objections would not necessarily defeat incorporation of the clause in all cases.

It is also an ill-conceived fear that incorporating third party benefits into resource extraction contracts will deter foreign investment. ${ }^{253}$ "[N]atural resources are available in commercial quantity in only a few countries, meaning that there is little room for forum shopping in terms of investment in natural resource exploitation." ${ }^{254}$ This creates intense competition for access to natural resources and, therefore, makes it unlikely that third party beneficiary provisions would scare away investors. ${ }^{255}$

Further, natural resource contracts between developing countries and foreign investors are often signed in secrecy, away from public forums such as Parliament. ${ }^{256}$ Having third party beneficiary status would permit third world communities to enforce natural resource contracts to benefit those most directly affected by natural resource extraction - typically themselves.

Investor rights have generally been jealously and vigorously protected by restrictive interpretations of contract doctrines that create little wiggle room to deviate from such rights. ${ }^{257}$ In this context arbitrators or courts may follow the same restrictive path by finding that for third party beneficiary claims to stand, the parties must be shown to have explicitly intended to create such rights.

\section{CONCLUSION}

In my view, third party beneficiary rights ought to be available to third world citizens so they can hold accountable both their governments and investors when natural resources are exploited. Requiring privity of contract

\footnotetext{
${ }^{252} I d$.

${ }^{253}$ See id. at 588-89 (assessing the merits of developing countries' concerns over incorporating OECD Guidelines into contracts, thereby establishing third party beneficiaries).

${ }_{254}^{25}$ Id.

${ }^{255}$ See id.

${ }^{256}$ For a great analysis, see Nicholas Miranda, Concession Agreements: From Private Contract to Public Policy, 117 Yale L.J. 510, 515-16 (2007) (noting in part that agreements such as natural resource concessions are often shielded "from public knowledge or influence: they provide the public with limited information ... and limited influence over the result").

${ }^{257}$ For an extensive analysis of this in the sovereign debt context see, James Gathii, The Sanctity of Sovereign Loan Contracts and Its Origins in Enforcement Litigation, 38 GEO. WASH. INT'L L. REV. 251 (2006).
} 
would ensure that citizens could not sue in contract when they are harmed. And, requiring privity is not the most logical approach - it is impossible to expect that citizens could be parties to a contract, and it is expected that governments contract on behalf of their citizens. For these reasons, the Third Party Beneficiary Principle is a vastly better alternative.

As mentioned above, natural resource contracts have a public nature. Resource extraction contracts between a government and foreign investor affect local citizens in profound and obvious ways. For example, citizens might be forced to relocate, food and water sources could be polluted beyond repair, and resources that local communities could use could become depleted. On the other hand, the benefits could be positive. Mining, transportation, or other jobs could be created for otherwise jobless and destitute citizens. Regardless of the actual outcome of these contracts, governments enter into these contracts for the benefit of local citizens. Because citizens are the intended beneficiaries of resource contracts, it only makes sense that they have rights in the event that any of the above harms occur.

Adopting third party beneficiary rights will not only provide tangible benefits to local citizens, but they will also be more-than-ideal replacements for the currently unenforceable remedies, like contract and revenue transparency, codes of conduct, and the U.N. Norms on Business and Human Rights. As currently applied, none of these approaches has been adequately enforceable, probably because they are voluntary and non-binding as a matter of law. The Third Party Beneficiary Principle would function as an important and necessary tool, supplementing these existing approaches. It would potentially solve problems that currently have no clear solutions.

An important contribution of recognizing the Third Party Beneficiary Principle is that it would set one of the background rules or one of the ground rules against which contracts for negotiation of extractive resources would be conducted. As a result, even if beneficiary communities were unable to pursue remedies in court, the recognition of the Third Party Beneficiary Principle would likely influence the negotiation of contracts by forcing the parties to take into account the rights of local communities.

Granting third world citizens third party beneficiary rights would not restrict investor's rights. ${ }^{258}$ The Third Party Beneficiary Principle would not necessarily bind investors to the law of the country and bar all international remedies-like arbitration. Instead, it would provide third world citizens with a mechanism with which they can enforce existing agreements and hold

${ }^{258}$ For a more in-depth discussion, see supra note 4 and surrounding text. 
responsible parties accountable in the event that harms occur. The risk to investors therefore is not a reduction of rights, but is instead the ability for citizens to sue when harms occur.

My argument in short has been that the Third Party Beneficiary Principle should become a background norm against which negotiations of resource contracts take place. In this context, governmental natural resource contracts would consider citizens as beneficiaries to the resources available in their countries. This approach would not only account for the rights of citizens, but would provide an avenue for redress in the event of harm to the citizens. Though not perfect, third party beneficiary rights would provide far better protection to citizens and would outperform any of the currently available remedies. 
